\title{
Effect of a surficial crust on mudmat capacity under fully three- dimensional loading
}

\author{
X. Feng ${ }^{1}$, S. Gourvenec ${ }^{1}$, M. F. Randolph ${ }^{1}$, R. Wallerand ${ }^{2}$ and P. Dimmock ${ }^{3}$ \\ Published in Géotechnique 65(7): 590-603. http://dx.doi.org/10.1680/geot./14-P-167
}

\author{
${ }^{1}$ Xiaowei FENG \\ Centre for Offshore Foundation Systems. A node of the ARC Centre of Excellence of \\ Geotechnical Science and Engineering - M053 \\ University of Western Australia \\ 35 Stirling Highway, Crawley \\ Perth, WA 6009 \\ Australia \\ Tel: +61 864882473 \\ Fax: +61 864881044 \\ Email: xiaowei.feng@uwa.edu.au

\section{Susan GOURVENEC} \\ Centre for Offshore Foundation Systems. A node of the ARC Centre of Excellence of \\ Geotechnical Science and Engineering \\ University of Western Australia \\ Tel: +61 864883094 \\ Email: susan.gourvenec@uwa.edu.au
}

\section{${ }^{1}$ Mark F. RANDOLPH}

Centre for Offshore Foundation Systems. A node of the ARC Centre of Excellence of Geotechnical Science and Engineering

University of Western Australia

Tel: +61 864883075

Email: mark.randolph@uwa.edu.au

\section{${ }^{2}$ Régis WALLERAND}

Subsea 7

Tel: +33 (0)1 40979007

Email: regis.wallerand@subsea7.com

\section{${ }^{3}$ Paul DIMMOCK}

BP Exploration Operating Company Limited

Tel: +44 (0)203 4017383

Email: paul.dimmock@uk.bp.com

No. of words: 4906 (without abstract and references)

No. of tables: 4, No. of figures: 25 


\title{
Effect of a surficial crust on mudmat capacity under fully three- dimensional loading
}

\author{
X. Feng ${ }^{1}$, S. Gourvenec ${ }^{1}$, M.F. Randolph ${ }^{1}$, R. Wallerand ${ }^{2}$ and P. Dimmock ${ }^{3}$
}

\begin{abstract}
Submarine sediments in many deep water regions exhibit a thin crust overlying geologically normally consolidated clay. Load-carrying capacity of mudmat foundations for supporting subsea infrastructure installed on seabeds with a surficial crust is of great interest to foundation designers. Finite element analyses have been performed to investigate the undrained response of mudmats under combined six degree-of-freedom loading in terms of the effect of crust thickness, foundation embedment and relative shear strengths of the underlying soft clay and crust. Results are presented as failure envelopes and expressions are presented to enable calculation of the uniaxial and combined load capacities under fully threedimensional loading.
\end{abstract}

\section{KEYWORDS}

clays; fabric/structure of soils; bearing capacity; footings/foundations; failure; offshore engineering

\footnotetext{
${ }^{1}$ Centre for Offshore Foundation Systems, The University of Western Australia

${ }^{2}$ Subsea 7

${ }^{3}$ BP Exploration Operating Company Limited
} 


\section{INTRODUCTION}

As oil and gas developments extend into deeper water and new geographical regions, a surficial seabed 'crust zone’ of anomalous high shear strength has been reported frequently in site investigations. The favoured origin of the crusts in deep water is suggested to be a product of bioturbation and geochemical transformation in sediments (Ehlers et al., 2005; Kuo \& Bolton, 2013). The results of cone penetration tests (CPTs) and T-bar tests (Stewart \& Randolph, 1994) indicate that the shear strength within the crust zone generally increases rapidly from the mudline to a maximum value of 5 to $15 \mathrm{kPa}$ at $0.5 \mathrm{~m}$ to $1 \mathrm{~m}$ depth, with the underlying soft clay exhibiting essentially normally consolidated (NC) conditions with strength increasing proportionally with depth (e.g. Ehlers et al., 2005; DeGroot et al., 2011). Two examples of the undrained shear strength profiles of a soft seabed with surficial crust in the upper few metres are shown in Figure 1. The soil properties of a crustal layer have been shown to have a significant impact on design of seabed pipelines (Kuo \& Bolton, 2014). This study addresses the effect of a surficial crust on the design of subsea shallow foundations, often referred to as mudmats. Subsea mudmats, generally rectangular in plan, are extensively deployed for supporting subsea equipment including pipeline end terminations (PLETs) or manifolds (PLEMs), and in-line sleds. For typical subsea mudmats with plan dimensions of around $10 \mathrm{~m}$ and embedment ratios of up to $20 \%$ of the foundation breadth, the soil-structure interaction generally takes place within the upper metre or two of the subsoil, thus coinciding with the zone of the crustal layer.

Most research on the response of shallow foundations on layered deposits has focused on the undrained ultimate vertical bearing capacity. The first rational approach to solve the bearing capacity problem for a strip foundation on two-layer soil was shown by Button (1953). The later solutions of Meyerhof and Hanna (1978) were based on small-scale tests from which semi-empirical formulations for the bearing capacity factor were developed. More recently, 
rigorous bound solutions for bearing capacity factors of a surface strip foundation on a twolayer clay profile have been obtained from finite-element limit analysis (Merifield et al., 1999). Michalowski (2002) examined the limit loads on a foundation over two-layer clay in consideration with load inclination. In an advance over the plane strain analyses outlined above, three-dimensional finite-element analysis was employed to calculate the bearing capacity of rectangular and square foundations on two-layered clays (e.g. Zhu and Michalowski, 2005; Merifield and Nguyen, 2006; Yu et al., 2011). However, those studies were mainly for cases where the undrained shear strength was uniform with depth in both soil strata.

Numerical studies of the vertical bearing capacity of strip and circular foundations on a nonhomogeneous crust overlying uniform soft clay were presented by Park et al. (2010). The results indicated insignificant difference in bearing capacity with either non-homogenous or uniform undrained shear strength distribution in the crust when $t_{c} / B<1.5$ and $t_{c} / D<1.0$ for strip and circular foundations, respectively, where $t_{c}$ is the thickness of the crust, B and D are the breadth or diameter of the strip or circular foundation respectively. The bearing capacity of a foundation on a deposit comprising a crust overlying a soil with linearly increasing undrained shear strength with depth, representative of normally consolidated (NC) clay, has not been addressed systematically.

Furthermore, existing studies have considered predominantly vertical load, and on occasion load inclination. However, the external loads transferred to mudmats are normally threedimensional because the associated pipelines and jumpers do not align in a single plane. The external loading transmitted to a subsea mudmat is represented schematically in Figure 2.

The work presented in this paper identifies the undrained load-carrying capacity of rectangular mudmats under fully three-dimensional loading, $\mathrm{V}-\mathrm{H}^{2}-\mathrm{M}^{2}-\mathrm{T}$ in soils with a crust overlying normally consolidated clay. Parametric studies address the effects of the relative 
crust thickness, foundation embedment ratio and the ratio of the shear strengths of clay immediately underlying the crust to that of the crust.

\section{DESIGN APPROACH FOR MUDMATS UNDER LOADING IN 6 DOF ON SINGLE LAYERED SOIL}

A design approach for assessing the undrained load-carrying capacity of mudmat foundations subjected to $\mathrm{V}-\mathrm{H}^{2}-\mathrm{M}^{2}-\mathrm{T}$ loading in a single layered soil with shear strength increasing linearly with depth was proposed by Feng et al. (2014b). The method involves defining the ultimate limit state of mudmats under combined six degree-of-freedom loading through a nest of twodimensional failure envelopes of the resultant horizontal and moment loading, accounting for mobilised vertical and torsional resistance. For a given foundation geometry and soil strength profile, the principal design steps in the approach are tabulated in Table 1.

The overall strategy for the $\mathrm{FE}$ analyses on the $\mathrm{V}-\mathrm{H}^{2}-\mathrm{M}^{2}-\mathrm{T}$ load-carrying capacity for mudmats founded in a crustal layer overlying normally consolidated clay is built on the framework for a single layer soil. Initially, the uniaxial capacities, i.e. for which a single component of load or moment acts on the foundation in isolation, are calculated. The available maximum horizontal, moment and torsional capacities are then examined according to the mobilised vertical resistance, involving identification of the $\mathrm{V}-\mathrm{H}_{\mathrm{x}(\mathrm{y})}, \mathrm{V}-\mathrm{M}_{\mathrm{x}(\mathrm{y})}$ and $\mathrm{V}-\mathrm{T}$ interaction diagrams. Subsequent analyses are performed to investigate the interaction diagrams under $\mathrm{H}_{\mathrm{x}}-\mathrm{H}_{\mathrm{y}}$ and $\mathrm{M}_{\mathrm{x}}-\mathrm{M}_{\mathrm{y}}$ loading, allowing estimation of the maximum horizontal and moment capacity for any angle of horizontal and moment loading, respectively. These maximum values are then reduced according to the mobilised torsion by considering the interaction diagram for H-T and M-T loading. Ultimately, a general formulation of a failure envelope is developed for the $\mathrm{V}-\mathrm{H}^{2}-\mathrm{M}^{2}-\mathrm{T}$ loading. An example of the failure envelopes derived from the design approach is presented in Figure 3 for a mudmat under fully threedimensional loading on single layered soil. 


\section{FINITE ELEMENT MODEL}

\section{Geometry and meshes}

All the FE analyses presented from this study were carried out using the commercially available software Abaqus (Dassault Systèmes, 2010).

The majority of the analyses considered a typical rectangular mudmat with breadth-to-length ratio of $\mathrm{B} / \mathrm{L}=0.5$ and two representative crusts with thickness ratio of $\mathrm{t}_{\mathrm{c}} / \mathrm{B}=0.1$ and 0.2 to bracket a practical range of field conditions. The base of the foundation (or skirt tip) was assumed to terminate within the crust, i.e. $d / t_{c} \leq 1$, with $d$ being the skirt depth. Accordingly, the foundation embedment ratio $\mathrm{d} / \mathrm{B}$ was varied from zero to 0.2 , again encompassing typical skirt depth ratios, which in many cases are less than 0.1 . Foundation geometries with $d>t_{c}$, would rarely represent an optimal design because of the typical reduction in shear strength immediately below the crust.

The three-dimensional finite element mesh used for the analysis of the rectangular mudmat is shown in Figure 4 (half view). The breadth was taken as $B=5 \mathrm{~m}$ for all of the analyses, but the results are presented in normalized quantities so that they are independent of the selected foundation size. The meshes extended 4B from the edges of the foundation and 4B beneath the foundation base level, with horizontally constrained nodes at the vertical sides, and fully constrained nodes across the base. The boundaries were shown to be sufficiently remote so that the failure mechanisms were unaffected. First order 8-node brick, hybrid elements were used. Hybrid elements are well-suited to model the response of near-incompressible materials (such as soil under undrained conditions). The mesh featured two thin layers of elements immediately beneath the foundation, at the soil interface, with the characteristic thickness being approximately $0.3 \% \mathrm{~B}$, to capture precisely the possible positions of the shear failure surface and to more accurately obtain the sliding resistance. 


\section{Materials and interfaces}

The soil shear strength profile consisted of a surficial crust with an underlying layer of normally consolidated clay. The range of shear strength profiles and the parameters describing the crustal configuration and relative undrained shear strength ratios considered in this study are defined in Figure 2. The shear strength of the crust, $\mathrm{s}_{\mathrm{ut}}$, was uniform and kept constant whereas the underlying layer was defined by assuming normally consolidated conditions, i.e. with zero shear strength at the mudline increasing proportionally with depth, z. The strength gradient, $\mathrm{k}$, for the lower clay was varied according to the desired soil layer strength ratio, $\mathrm{subs}_{\mathrm{u}} / \mathrm{sut}_{\mathrm{u}}$, with $\mathrm{Subs}_{\mathrm{u}}\left(=\mathrm{kt}_{\mathrm{c}}\right)$ being the shear strength of the base clay at the interface. The crust strength was prescribed a value of $10 \mathrm{kPa}$ based on available site information, but the results are presented in terms of dimensionless groups such that the absolute magnitude defined in the analyses is irrelevant. The strength heterogeneity for the underlying soil was defined by a non-dimensional quantity, denoted as $\kappa=\mathrm{kB} / \mathrm{subs}_{\mathrm{bs}}=\mathrm{B} / \mathrm{t}_{\mathrm{c}}$. Soil strength profiles considered ranged from a strong crust overlying a very weak sublayer, with the undrained strength at the interface up to 20 times smaller than the shear strength of the crust, $\mathrm{subs}_{\mathrm{ut}} / \mathrm{s}_{\mathrm{ut}}=$ 0.05 , to a crust underlain by a sublayer of equal shear strength at the interface and increasing linearly with depth $\mathrm{s}_{\mathrm{ubs}} / \mathrm{s}_{\mathrm{ut}}=1.0$ (Figure 2). In total seven variations of crust configuration, $\mathrm{Subs}_{\mathrm{ub}} / \mathrm{s}_{\mathrm{ut}}$, were considered and two normalised crust thickness, $\mathrm{t}_{\mathrm{c}} / \mathrm{B}$.

The assumption of a uniform shear strength in the crust layer is an idealisation of field conditions, which span from the more 'triangular' distribution observed in Figure 1a, to the more uniform profile representative of other field strength profiles, such as shown in Figure 1b. A uniform shear strength in the crust was selected as it allowed for relatively straightforward definition of the dimensionless groups for shear strength $\left(\mathrm{s}_{\mathrm{ubs}} / \mathrm{s}_{\mathrm{ut}}\right.$ and $\kappa=$ $\mathrm{kB} / \mathrm{s}_{\mathrm{ubs}}=\mathrm{B} / \mathrm{t}_{\mathrm{c}}$ ) and the subsequent synthesis of the results in terms of embedment ratio, $\mathrm{d} / \mathrm{B}$, and normalised crust thickness, $\mathrm{t}_{\mathrm{c}} / \mathrm{B}$. Engineering judgement is required in every case to select 
the magnitude of the uniform design strength in relation to field conditions, soil behaviour and operational requirements. Such an idealisation is illustrated on Figure 1a and is subsequently adopted for the worked examples presented at the end of the paper.

The soil was modelled as linear elastic, perfectly plastic obeying a Tresca failure criterion. The elastic properties were defined by undrained Young's modulus $\mathrm{E}=600 \mathrm{~s}_{\mathrm{u}}$ and Poisson's ratio of $v=0.49$ (to avoid numerical difficulties associated with the constant-volume response of the soil under undrained conditions). This gave a relatively high rigidity index $\mathrm{G} / \mathrm{S}_{\mathrm{u}}$ of 200 , where $G$ is the shear modulus of the soil, so that failure occurred at relatively small displacements to avoid problems of mesh distortion.

The skirted foundation was idealised as an equivalent embedded solid foundation on the assumption that in practice, sufficient internal skirts would be provided so that the soil plug enclosed by the peripheral skirts would displace as an intact body with the foundation during undrained loading. The required number of internal skirts to achieve optimal capacity of rectangular mudmats under $\mathrm{V}-\mathrm{H}^{2}-\mathrm{M}^{2}-\mathrm{T}$ loading has been previously quantified (Feng, et al., 2014a). The solid foundation was modelled as a rigid body with a load reference point (LRP) defined at the centroid of the foundation at mudline level. In the analysis, all foundation loads and displacements were applied or recovered at this point.

The interface between the underside of the rigid solid foundation and the subsoil was taken to be rough in shear with no detachment between the mudmat and soil permitted (i.e. fully bonded) to represent the 'rough' soil-soil interface at skirt tip level of a skirted foundation. The contact between the external faces of the peripheral skirts and the adjacent soil was modelled as frictionless with separation permitted, avoiding transmission of any tensile normal stress across the interface. 


\section{Load path}

The response of the mudmat foundations subjected to $\mathrm{V}-\mathrm{H}^{2}-\mathrm{M}^{2}-\mathrm{T}$ loading is presented in the form of failure envelopes. Failure envelopes under combined loading conditions are generally evaluated through swipe tests or fixed ratio displacement probes. Sideswipe tests, which have been used in previous experimental and numerical work, take advantage of allowing large sections of failure envelope to be investigated in a single analysis (e.g. Tan, 1990; Gourvenec \& Randolph, 2003). However, fixed ratio displacement controlled probe tests were adopted in this study because the load path in a sideswipe test can undercut the true failure envelope, particularly for embedded foundations (Gourvenec, 2008).

\section{Model validation}

The FE model was validated first by calculating the uniaxial capacity of a surface rectangular foundation on a uniform single layer soil. The vertical bearing capacity obtained was $\mathrm{V}_{\mathrm{ult}} / \mathrm{As}_{\mathrm{u}}$ $=5.65$ which compares well with the best-estimate value of 5.63 proposed by Gourvenec et al. (2006) based on upper bound solutions and FEA. The horizontal capacities obtained numerically were $\mathrm{H}_{\mathrm{xult}} / \mathrm{As}_{\mathrm{u}}=1.05$ and $\mathrm{H}_{\text {yult }} / \mathrm{As}_{\mathrm{u}}=1.04$, slightly above the theoretical value of unity from a pure sliding mechanism of a surface foundation, the difference arising from shearing in the uppermost soil element of small but finite thickness as opposed to directly at the soil-foundation interface. Moment capacity factors of $\mathrm{M}_{\text {yult }} / \mathrm{ABs}_{\mathrm{u}}=0.82$ and $\mathrm{M}_{\mathrm{xult}} / \mathrm{ALs}_{\mathrm{u}}=1.04$ were obtained. No analytical solutions exist for comparison, but the results agree with the previous FE results reported by Gourvenec (2007). The undrained torsional capacity of $\mathrm{T}_{\mathrm{ult}} / \mathrm{ALs}_{\mathrm{u}}=0.317$ obtained numerically is approximately $7 \%$ greater than the analytical solution of 0.297 derived by Murff et al. (2010) (see Equation (11)).

Validation of the layered model considered a strip and square foundation with identical mesh discretisation on the mid-point central plane as shown in Figure 4. The vertical bearing capacity of the strip foundation on a stiff-over-soft clay is well bracketed by the upper bound 
(UB) and lower bound (LB) solutions by Merifield et al. (1999) as shown in Figure 5a. For the square foundation, the FE results show good agreement with those from Merifield and Nguyen (2006) (Figure 5b).

\section{RESULTS}

All results in this paper are presented as non-dimensional quantities, with the load capacity normalised as, V/Asut, $\mathrm{H}_{\mathrm{x}(\mathrm{y})} / \mathrm{As}_{\mathrm{ut}}, \mathrm{M}_{\mathrm{y}} / \mathrm{Abs}_{\mathrm{ut}}, \mathrm{M}_{\mathrm{x}} / \mathrm{Als}_{\mathrm{ut}}$ and T/Alsut.

\section{Pure uniaxial capacity}

\section{Vertical bearing capacity}

The undrained vertical bearing resistance of a shallow foundation in a deposit comprising a strong crust over a weaker layer was found to be a complex function of a number of dimensionless factors: (a) the shear strength ratio between the underlying weaker layer and the stronger top crust, $\mathrm{s}_{\mathrm{ubs}} / \mathrm{s}_{\mathrm{ut}}$, which reflects the effects of the shear strength distribution of the underlying layer; (b) the thickness of the crust relative to the foundation width, $\mathrm{t}_{\mathrm{c}} / \mathrm{B}$; and (c) the foundation embedment relative to the thickness of crust layer, $d / t_{c}$.

The normalised vertical bearing capacity was able to be represented by the expression

$$
\frac{\mathrm{V}_{\mathrm{ult}}}{\mathrm{As}_{\mathrm{ut}}}=\mathrm{a}_{1}\left(\frac{\mathrm{s}_{\mathrm{ubs}}}{\mathrm{s}_{\mathrm{ut}}}\right)^{\mathrm{a}_{2}}
$$

where the coefficient $\mathrm{a}_{1}$ and the power $\mathrm{a}_{2}$ are a function of the relative foundation embedment, $\mathrm{d} / \mathrm{t}_{\mathrm{c}}$, and crust thickness, $\mathrm{t}_{\mathrm{c}} / \mathrm{B}$. The best estimate of undrained vertical capacity for foundations in a deposit comprising a strong crust overlying a weaker clay (see Figure 6) was achieved with 


$$
\begin{aligned}
& \mathrm{a}_{1}=\left(-5.063 \frac{\mathrm{t}_{\mathrm{c}}}{\mathrm{B}}+5.312\right) \frac{\mathrm{d}}{\mathrm{t}_{\mathrm{c}}}+3.943\left(\frac{\mathrm{t}_{\mathrm{c}}}{\mathrm{B}}\right)^{-0.3504} \\
& \mathrm{a}_{2}=\left(1.823 \frac{\mathrm{t}_{\mathrm{c}}}{\mathrm{B}}+0.061\right) \frac{\mathrm{d}}{\mathrm{t}_{\mathrm{c}}}+\left(-1.895 \frac{\mathrm{t}_{\mathrm{c}}}{\mathrm{B}}+0.806\right)
\end{aligned}
$$

\section{Moment capacities}

Soil bearing failure occurs within both the crust and underlying soft clay for a foundation under pure moment, so the factors affecting the moment capacity are the same as those affecting vertical bearing capacity. Therefore, a similar form of expression was employed to fit the pure moment capacities.

The ultimate moment capacity about the y-axis (Figure 7) can be estimated by

$$
\frac{\mathrm{M}_{\text {yult }}}{\mathrm{ABs}_{\mathrm{ut}}}=\mathrm{b}_{1}\left(\frac{\mathrm{s}_{\mathrm{ubs}}}{\mathrm{s}_{\mathrm{ut}}}\right)^{\mathrm{b}_{2}}
$$

with

$$
\begin{aligned}
& \mathrm{b}_{1}=\left(-1.920 \frac{\mathrm{t}_{\mathrm{c}}}{\mathrm{B}}+1.107\right) \frac{\mathrm{d}}{\mathrm{t}_{\mathrm{c}}}+0.434\left(\frac{\mathrm{t}_{\mathrm{c}}}{\mathrm{B}}\right)^{-0.4672} \\
& \mathrm{~b}_{2}=\left(1.548 \frac{\mathrm{t}_{\mathrm{c}}}{\mathrm{B}}+0.108\right) \frac{\mathrm{d}}{\mathrm{t}_{\mathrm{c}}}+\left(-2.435 \frac{\mathrm{t}_{\mathrm{c}}}{\mathrm{B}}+0.802\right)
\end{aligned}
$$

The ultimate moment capacity about the x-axis (Figure 8) can be estimated by

$$
\frac{\mathrm{M}_{\text {xult }}}{\mathrm{ALs}_{\mathrm{ut}}}=\mathrm{c}_{1}\left(\frac{\mathrm{s}_{\mathrm{ubs}}}{\mathrm{s}_{\mathrm{ut}}}\right)^{\mathrm{c}_{2}}
$$

with

$$
\begin{aligned}
& \mathrm{c}_{1}=\left(-1.040 \frac{\mathrm{t}_{\mathrm{c}}}{\mathrm{B}}+1.161\right) \frac{\mathrm{d}}{\mathrm{t}_{\mathrm{c}}}+0.701\left(\frac{\mathrm{t}_{\mathrm{c}}}{\mathrm{B}}\right)^{-0.426} \\
& \mathrm{c}_{2}=\left(1.550 \frac{\mathrm{t}_{\mathrm{c}}}{\mathrm{B}}+0.099\right) \frac{\mathrm{d}}{\mathrm{t}_{\mathrm{c}}}+\left(-1.719 \frac{\mathrm{t}_{\mathrm{c}}}{\mathrm{B}}+0.776\right)
\end{aligned}
$$




\section{Horizontal capacity}

Observed soil failure mechanisms under purely horizontal load, for two different values of $\mathrm{sub}_{\mathrm{ub}} / \mathrm{sut}_{\mathrm{ut}}$, for $\mathrm{d} / \mathrm{t}_{\mathrm{c}}=0.5$, are shown in Figure 9 . Horizontal capacity is governed mostly by the local soil shear strength above skirt tip level. The soil shear failure surface occurs where the least resistance is provided, in accordance with the principle of minimum plastic work. Hence, when the distance between foundation skirt tip and the soil layer interface is sufficiently large (Figure 9b), the foundation will behave as if embedded only in the upper crust since greater plastic work within the soil would be needed to mobilise a deeper soil shear failure in the underlying clay, even though the undrained shear strength might be much smaller at the soil layer interface. Therefore, the horizontal capacity can be determined just as for a foundation in single layered uniform soil if foundation performance is unaffected by the underlying soil. For a uniform crust this can be expressed as

$$
\begin{aligned}
& \frac{\mathrm{H}_{\text {xult_1 }}}{\mathrm{As}_{\mathrm{ut}}}=1+\frac{\mathrm{d}}{\mathrm{B}} \mathrm{N}_{\mathrm{p}} \\
& \frac{\mathrm{H}_{\text {yult_1 }}}{\mathrm{As}_{\mathrm{ut}}}=1+\frac{\mathrm{d}}{\mathrm{L}} \mathrm{N}_{\mathrm{p}}
\end{aligned}
$$

where $\mathrm{N}_{\mathrm{p}}$ is the skirt bearing factor, expressed as $2.2+\gamma^{\prime} \mathrm{d} / 2 \mathrm{~s}_{\mathrm{ut}} \leq 4.4$ (Feng et al., 2014b).

As the ratio of foundation embedment to crust thickness, $d / t_{c}$, increases beyond a certain value, the shear failure surface will occur either at the level of the soil layer interface or the foundation base, with the position depending on the shear strength ratio, $\mathrm{s}_{\mathrm{ubs}} / \mathrm{s}_{\mathrm{ut}}$. For the lower strength ratio the failure mechanism extends down to the soil layer interface (Figure 9a), while for the higher strength ratio, the failure mechanism is contained within the crust (Figure 9b). The corresponding horizontal capacities can be expressed as 


$$
\begin{aligned}
& \frac{\mathrm{H}_{\text {xult_2 }}}{\mathrm{As}_{\mathrm{ut}}}=\left(1+2 \frac{\mathrm{t}_{\mathrm{c}}-\mathrm{d}}{\mathrm{B}}\right) \frac{\mathrm{s}_{\mathrm{ubs}}}{\mathrm{s}_{\mathrm{ut}}}+\mathrm{N}_{\mathrm{H}_{\mathrm{x}}} \frac{\mathrm{t}_{\mathrm{c}}-\mathrm{d}}{\mathrm{B}}+\frac{\mathrm{d}}{\mathrm{B}} \mathrm{N}_{\mathrm{p}} \\
& \frac{\mathrm{H}_{\text {yult_2}}}{A \mathrm{~s}_{\mathrm{ut}}}=\left(1+2 \frac{\mathrm{t}_{\mathrm{c}}-\mathrm{d}}{\mathrm{L}}\right) \frac{\mathrm{s}_{\mathrm{ubs}}}{\mathrm{s}_{\mathrm{ut}}}+\mathrm{N}_{\mathrm{H}_{\mathrm{y}}} \frac{\mathrm{t}_{\mathrm{c}}-\mathrm{d}}{\mathrm{L}}+\frac{\mathrm{d}}{\mathrm{L}} \mathrm{N}_{\mathrm{p}}
\end{aligned}
$$

where $\mathrm{N}_{\mathrm{Hx}}$ and $\mathrm{N}_{\mathrm{Hy}}$ were taken as 5.2 and 8.8 respectively to yield the best estimate of the $\mathrm{FE}$ results. Figure 10 and Figure 11 show that the horizontal capacity for a given foundation embedment increases with increasing $\mathrm{s}_{\mathrm{ubs}} / \mathrm{s}_{\mathrm{ut}}$ and ultimately approaches a plateau, indicating that the shear failure surface gradually transfers from the level of the soil interface to the foundation base.

In general, horizontal capacities for a rectangular mudmat embedded in soil with crustal layer can be predicted as follows

$$
\begin{aligned}
& \frac{\mathrm{H}_{\text {xult }}}{A s_{\mathrm{ut}}}=\min \left(\frac{\mathrm{H}_{\text {xult_1 }}}{A s_{\mathrm{ut}}}, \frac{\mathrm{H}_{\text {xult_2 }}}{A s_{\mathrm{ut}}}\right) \\
& \frac{\mathrm{H}_{\text {yult }}}{\mathrm{As}_{\mathrm{ut}}}=\min \left(\frac{\mathrm{H}_{\text {yult_1 }}}{\mathrm{As}_{\mathrm{ut}}}, \frac{\mathrm{H}_{\text {yult_2 }}}{\mathrm{As}_{\mathrm{ut}}}\right)
\end{aligned}
$$

The finite element results are expected to over-predict sliding resistance due to numerical approximation of shearing in a band of thin but finite thickness elements directly beneath the foundation, with numerical over-prediction greatest in the profiles of high strength heterogeneity. Over-estimation up to $6 \%$ was observed in the FE results for surface foundations with high $\mathrm{kB} / \mathrm{s}_{\mathrm{u}}$, compared with the theoretical prediction of $\mathrm{H}_{\mathrm{ult}} / \mathrm{As}_{\mathrm{u}}=1$.

\section{Torsional capacity}

For a foundation under ultimate horizontal or torsional load, the developed failure mechanism involves soil shearing at skirt tip level, and passive and active (if available) failure against the skirts. Therefore, the expressions for predicting torsional capacity follow similar forms to those for horizontal capacity. 
When foundation embedment is sufficiently small, torsional capacity can be calculated by

$$
\frac{\mathrm{T}_{\mathrm{ult} \_1}}{\mathrm{ALs}_{\mathrm{ut}}}=\mathrm{t}_{\mathrm{s}}+\frac{\mathrm{d}}{\mathrm{B}} \frac{\mathrm{N}_{\mathrm{p}}}{4}\left(1+\left(\frac{\mathrm{B}}{\mathrm{L}}\right)^{2}\right)
$$

with $t_{s}$ being the normalised torsional capacity for a surface foundation:

$$
\mathrm{t}_{\mathrm{s}}=\frac{4}{\mathrm{AL}} \int_{0}^{\mathrm{B} / 2} \int_{0}^{\mathrm{L} / 2} \sqrt{\mathrm{x}^{2}+\mathrm{y}^{2}} \mathrm{dx} d \mathrm{y}
$$

and $\mathrm{N}_{\mathrm{p}}$ the skirt bearing factor, expressed as $2.5+\gamma^{\prime} \mathrm{d} / 2 \mathrm{sut}_{\mathrm{ut}} \leq 5.0$ (Feng et al., 2014b).

As foundation embedment increases beyond a certain value, the torsional capacity develops as

$$
\frac{\mathrm{T}_{\mathrm{ult} 2} 2}{\mathrm{ALs}_{\mathrm{ut}}}=\left(\mathrm{t}_{\mathrm{s}}+\frac{\mathrm{t}_{\mathrm{c}}-\mathrm{d}}{2 \mathrm{~B}}\left(1+\left(\frac{\mathrm{B}}{\mathrm{L}}\right)^{2}\right)\right) \frac{\mathrm{s}_{\mathrm{ubs}}}{\mathrm{s}_{\mathrm{ut}}}+\frac{1}{4}\left(\mathrm{~N}_{\mathrm{T}} \frac{\mathrm{t}_{\mathrm{c}}-\mathrm{d}}{\mathrm{B}}+\mathrm{N}_{\mathrm{p}} \frac{\mathrm{d}}{\mathrm{B}}\right)\left(1+\left(\frac{\mathrm{B}}{\mathrm{L}}\right)^{2}\right)
$$

where $\mathrm{N}_{\mathrm{T}}$ is taken as 5.6.

The general formulation of the torsional capacity for given foundation embedment is therefore given as follows

$$
\frac{\mathrm{T}_{\mathrm{ult}}}{\mathrm{ALs}_{\mathrm{ut}}}=\min \left(\frac{\mathrm{T}_{\mathrm{ult} \_1}}{\mathrm{ALs}_{\mathrm{ut}}}, \frac{\mathrm{T}_{\mathrm{ult} \_2}}{\mathrm{ALs}_{\mathrm{ut}}}\right)
$$

The quality of the proposed curve fit is shown in Figure 12.

\section{Combined loading including V}

\section{Combined V-H loading capacity}

Previous studies have shown that foundation embedment and soil heterogeneity have insignificant effects on the shape of normalised failure envelopes in vertical and horizontal load space $(\mathrm{M}=\mathrm{T}=0$ ). Figure 13 shows that the normalised $\mathrm{V}-\mathrm{H}$ failure envelopes fall in a tight band for subsoil with two extreme strength ratios, and for foundations with different embedment. The failure envelopes can be approximated by a piecewise function using the 
same expression proposed for the case of single layered soil (Feng et al., 2014b). For a typical mudmat design, the mobilised vertical capacity, $\mathrm{V} / \mathrm{V}_{\text {ult, }}$ is generally less than $30 \%$, for which the reduction in horizontal capacity due to vertical load is negligibly small (see Figure 13).

The V-H envelopes may be represented by

$\mathrm{h}=1$, for $\mathrm{v} \leq 0.4$

and

$\mathrm{v}=0.4+0.6 \sqrt{1-\mathrm{h}^{2.5-\cos ^{2} \theta}}$, for $\mathrm{v}>0.4$

where $\mathrm{v}$, h represent the mobilised capacities $\mathrm{V} / \mathrm{V}_{\text {ult }}$ and $\mathrm{H} / \mathrm{H}_{\text {ult }}$, respectively.

\section{Combined V-M loading capacity}

The failure envelopes in normalised V-M loading space $(\mathrm{H}=\mathrm{T}=0)$ may be fitted accurately by a simple power law curve of the form (Gourvenec and Randolph, 2003)

$$
\mathbf{v}=(1-\mathrm{m})^{\mathrm{P}}
$$

with $\mathrm{m}=\mathrm{M} / \mathrm{M}_{\mathrm{ult}}$ and $\mathrm{p}$ being a function of the aspect ratio and soil heterogeneity of underlying soil. For moment loading about the long axis (i.e. the $\mathrm{V}-\mathrm{M}_{\mathrm{y}}$ plane), the exponent derived from finite element results is essentially independent of the crust thickness and may be expressed as

$$
\mathrm{p}=0.23\left(1+0.19 \kappa-0.02 \kappa^{2}+0.001 \kappa^{3}\right)\left[1+0.4 \frac{\mathrm{B}}{\mathrm{L}}-0.1\left(\frac{\mathrm{B}}{\mathrm{L}}\right)^{2}\right]
$$

The same expression can be used for moment loading about the short axis ( $V-M_{x}$ plane), but replacing $\mathrm{B} / \mathrm{L}$ by $\mathrm{L} / \mathrm{B}$. Reasonable estimation is achieved for most soil conditions and the power law relationship becomes increasingly conservative in the $\mathrm{V}-\mathrm{M}_{\mathrm{x}}$ loading plane as the shear strength ratio decreases (Figure 14). 


\section{Combined V-T loading capacity}

Figure 11 shows that the normalised V-T failure envelopes (with $\mathrm{t}=\mathrm{T} / \mathrm{T}_{\text {ult }}$ ) are only slightly influenced by the strength ratio, but are more strongly affected by the relative foundation embedment in the crust. Under combined vertical and torsional loading, the FE results fit a failure envelope, given by

For $\mathrm{v} \leq 0.4, \mathrm{t}=1$

For $\mathrm{t}<1, \mathrm{v}=0.4+0.6 \sqrt{1-\mathrm{t}^{6\left(\mathrm{~d} / \mathrm{t}_{\mathrm{c}}-0.5\right)^{2}+2}}$

\section{Resultant horizontal and moment capacities}

After establishing the uniaxial capacities, the maximum horizontal and moment capacity for any given arbitrary loading angles $\theta$ and $\theta_{\mathrm{m}}$ (Figure 16) can be identified on the failure envelopes for $\mathrm{H}_{\mathrm{x}}-\mathrm{H}_{\mathrm{y}}$ and $\mathrm{M}_{\mathrm{y}}-\mathrm{M}_{\mathrm{x}}$ loading, respectively.

The ultimate horizontal capacity, denoted as $\mathrm{H}_{\mathrm{ult}}$, can be explored on the $\mathrm{H}_{\mathrm{x}}-\mathrm{H}_{\mathrm{y}}$ failure envelope associated with the loading direction of $\theta=\tan ^{-1}\left(\mathrm{H}_{\mathrm{y}} / \mathrm{H}_{\mathrm{x}}\right)$. A general ellipse was proposed by Feng, et al. (2104b) for the normalised $\mathrm{H}_{\mathrm{x}}-\mathrm{H}_{\mathrm{y}}$ failure envelopes to determine the horizontal capacity of a rectangular mudmat embedded in a single layered soil, given by

$$
\left(\frac{\mathrm{H}_{\mathrm{x}}}{\mathrm{H}_{\text {xult }}}\right)^{2+6 \frac{\mathrm{d}}{\mathrm{B}}}+\left(\frac{\mathrm{H}_{\mathrm{y}}}{\mathrm{H}_{\text {yult }}}\right)^{2}=1
$$

For foundations in a crust layer of given thickness ratio, $t_{c} / B$, the normalised $\mathrm{H}_{\mathrm{x}}-\mathrm{H}_{\mathrm{y}}$ failure envelopes were found to contract inward with increasing strength ratio and eventually converge (for $\mathrm{Subs}_{\mathrm{u}} / \mathrm{S}_{\mathrm{ut}}=1$ ) at the failure envelopes given by Equation (18) (see Figure 17). Thus, for high strength ratios the failure mechanisms were confined within the upper crust and the interaction envelopes were not affected by the underlying soil layer (Figure 17). For 
general application, incorporating the effects of relative crust thickness and shear strength ratio, Equation (18) can be adjusted to

$$
\left(\frac{\mathrm{H}_{\mathrm{x}}}{\mathrm{H}_{\text {xult }}}\right)^{2+6 \frac{\mathrm{d}}{\mathrm{B}}}+\left(\frac{\mathrm{H}_{\mathrm{y}}}{\mathrm{H}_{\text {yult }}}\right)^{\max (\xi, 2)}=1
$$

where

$\xi=2\left(\frac{\mathrm{s}_{\mathrm{ubs}}}{\mathrm{s}_{\mathrm{ut}}}\right)^{10\left(1-2 \frac{\mathrm{t}_{\mathrm{c}}}{\mathrm{B}}\right) \frac{\mathrm{t}_{\mathrm{c}}-\mathrm{d}}{\mathrm{B}}-2 \frac{\mathrm{t}_{\mathrm{c}}}{\mathrm{B}}-0.4}$

It is seen in Figure 17 that the modified envelopes fit the FE results accurately.

The normalised $\mathrm{M}_{\mathrm{y}}-\mathrm{M}_{\mathrm{x}}$ failure envelopes are shown to be insensitive to the foundation embedment and crust thickness but change significantly with shear strength distribution of the underlying soil. This effect can be captured by

$$
\left(\frac{M_{x}}{M_{\text {xult }}}\right)^{3-0 . \frac{k B}{s_{u t}}}+\left(\frac{M_{y}}{M_{\text {yult }}}\right)^{1.5}=1
$$

as shown in Figure 18.

\section{Torsion effect on horizontal and moment capacities}

The ultimate horizontal load or moment is effectively reduced by the associated torsion. Torsion effects on horizontal and moment capacity were explored by analysing the $\mathrm{H}-\mathrm{T}$ and M-T failure envelopes, respectively.

It can be seen from Figure 19 that the innermost failure envelope corresponds to $\mathrm{H}$ being applied along the short axis (i.e. parallel to B). The envelope expands outwards as the horizontal loading direction changes from $0^{\circ}$ to $90^{\circ}$, that is, higher torsional resistance is available when the horizontal loading acts parallel to the long edge of the foundation, 
reflecting the results by Feng et al. (2014b). Furthermore, the H-T failure envelopes are independent of the foundation embedment and strength ratio for the case of the horizontal load being parallel to the short edge (Figure 20a). The effect of foundation embedment becomes increasingly pronounced with decreasing strength ratio as horizontal loading direction varies from $0^{\circ}$ to $90^{\circ}$ (Figure $20 \mathrm{~b}$ and c).

The general relationship between torsion and horizontal load proposed by Finnie and Morgan (2004) can be applied to estimate the combined H-T loading capacity.

$$
\left(\frac{\mathrm{H}}{\mathrm{H}_{\mathrm{ult}}}\right)^{\mathrm{m}}+\left(\frac{\mathrm{T}}{\mathrm{T}_{\mathrm{ult}}}\right)^{\mathrm{n}}=1
$$

The power m generally ranges from 1 to 2 for a rectangular foundation whereas the power $n$ was found to be a function of the foundation embedment, horizontal loading direction and shear strength ratio. General expressions have been derived for the powers $\mathrm{m}$ and $\mathrm{n}$ for the conditions in this study

$\mathrm{m}=1.85$

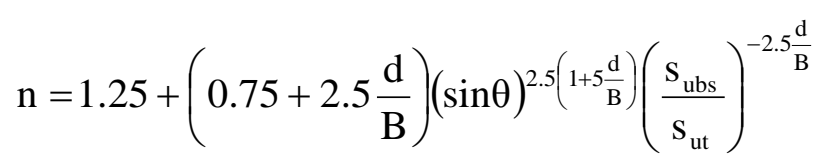

Normalised moment-torsion, M-T, failure envelopes were also explored for mudmats with embedment ratio $\mathrm{d} / \mathrm{B}=0,0.1$, and 0.2 , on soil with shear strength ratio $\mathrm{s}_{\mathrm{ubs}} / \mathrm{s}_{\mathrm{ut}}=0.1,0.25$ and 1 , for given crust thickness ratio of $t_{c} / B=0.2$. FE results indicate that the shape of the failure envelopes depends significantly on the foundation embedment relative to the thickness of the crust layer, $d / t_{c}$. Figure 21 plots the FE data points with respect to the general form of the failure envelopes expressed by

$$
\left(\frac{\mathrm{M}}{\mathrm{M}_{\text {ult }}}\right)^{6\left(0.583-0.167\left(\frac{\mathrm{d}}{\mathrm{t}_{\mathrm{c}}}\right)^{0.1}\right)}+\left(\frac{\mathrm{T}}{\mathrm{T}_{\text {ult }}}\right)^{2\left(1+\frac{\mathrm{d}}{\mathrm{t}_{\mathrm{c}}}\right)}=1
$$


The fit is generally conservative for all conditions considered.

\section{Combined M-H Failure Envelopes}

For a single layer soil, the shape of the normalised H-M failure envelope was found to be independent of foundation embedment provided the moment reference point was shifted from mudline to the level of the foundation base, that is by substituting a moment of $M^{*}=M+H d$. The same approach was applied in this study, and the FE results indicate that the failure envelope is relatively insensitive to foundation embedment and crust thickness.

Figure 22 and Figure 23 show the normalised $H_{x}-M_{y}$ and $H_{y}-M_{x}$ failure envelopes for different strength ratios and foundation embedment respectively. The failure envelopes may be expressed as

$$
\left(\frac{\mathrm{M}^{*}}{\mathrm{M}^{*} \text { ult }} \frac{\mathrm{M}^{*}}{\left|\mathrm{M}^{*}\right|}-\alpha_{0} \frac{\mathrm{H}}{\mathrm{H}_{\mathrm{ult}}} \frac{\mathrm{M}^{*}}{\left|\mathrm{M}^{*}\right|}+\beta_{0}\left(\frac{\mathrm{H}}{\mathrm{H}_{\mathrm{ult}}}\right)^{2}\right)^{3}\left(1-0.9 \frac{\mathrm{H}}{\mathrm{H}_{\mathrm{ult}}} \frac{\mathrm{M}^{*}}{\left|\mathrm{M}^{*}\right|}\right)+\left(\frac{\mathrm{H}}{\mathrm{H}_{\mathrm{ult}}}\right)^{2}=1
$$

where

$$
\begin{aligned}
& \alpha_{0}=0.05\left(\cos ^{2} \theta-\sin ^{2} \theta\right) \\
& \beta_{0}=0.1\left(\cos ^{2} \theta+2 \sin ^{2} \theta\right)
\end{aligned}
$$

with $\theta$ being the angle of the resultant horizontal load from the $\mathrm{x}$-axis.

Torsion has a significant effect on the HM failure envelopes, since it effectively reduces the maximum horizontal load and moment that can be sustained. The FE results indicate that the normalized H-M failure envelopes contract inwards with increasing mobilised torsion, $\mathrm{T} / \mathrm{T}_{\text {ult, }}$, with slightly greater reduction in the maximum sustainable horizontal load compared with the maximum moment. This is consistent with the influence of torsion being most significant where sliding failure occurs and least significant where deep bearing failure occurs. Because of the application of the torsion, the mudmat performs as if it was embedded in a soil with 
'reduced' shear strength at the level of the sliding failure surface. The H-M interaction mechanism is largely unaffected and a similar shape of failure envelope is maintained, although the aspect ratio reduces as the torsion level increases.

For any given magnitude of mobilised torsion, $\mathrm{T} / \mathrm{T}_{\text {ult }}$, the failure envelope can be estimated by substituting $\mathrm{H}_{\mathrm{ult}}$ and $\mathrm{M}_{\text {ult }}$ in Equation (25) by the corresponding maximum values $\mathrm{H}_{\max }$ and $\mathrm{M}_{\max }$ deduced from Equation (22) and (24), respectively.

$$
\left(\frac{\mathrm{M}^{*}}{\mathrm{M}_{\max }} \frac{\mathrm{M}^{*}}{\left|\mathrm{M}^{*}\right|}-\alpha_{0} \frac{\mathrm{H}}{\mathrm{H}_{\max }} \frac{\mathrm{M}^{*}}{\left|\mathrm{M}^{*}\right|}+\beta_{0}\left(\frac{\mathrm{H}}{\mathrm{H}_{\max }}\right)^{2}\right)^{3}\left(1-0.9 \frac{\mathrm{H}}{\mathrm{H}_{\max }} \frac{\mathrm{M}^{*}}{\left|\mathrm{M}^{*}\right|}\right)+\left(\frac{\mathrm{H}}{\mathrm{H}_{\max }}\right)^{2}=1
$$

A comparison of the reduced failure envelopes in the $\mathrm{H}_{\mathrm{x}}-\mathrm{M}_{\mathrm{y}}$ plane with FE results is shown in Figure 24, showing good agreement.

\section{EXAMPLE APPLICATIONS}

Example applications are considered here to illustrate the impact of a surficial crust on mudmat design. The undrained shear strength profiles shown in Figure 1 are accordingly idealised as a seabed with a surficial crust $\left(\mathrm{t}_{\mathrm{c}}=1 \mathrm{~m} ; \mathrm{s}_{\mathrm{ut}}=10 \mathrm{kPa}, \mathrm{k}=1.7 \mathrm{kPa} / \mathrm{m}\right.$ giving $\mathrm{s}_{\mathrm{ubs}}=$ $1.7 \mathrm{kPa}$ ), or approximated by a single layer seabed, i.e. neglecting the crust $\left(\mathrm{s}_{\mathrm{u}}=2+\right.$ $1.3 \mathrm{z} \mathrm{kPa}$ ). The single layer shear strength profile assumes a small non-zero mudline strength in recognition of the underestimation of strength in the crust. The crustal profile considered here is constrained to zero strength intercept, underestimating the shear strength of the immediate underlying soil, but the improvement in the foundation capacities is still significant by explicitly considering the crust as shown in the following example applications. The effective soil unit weight is taken as $\gamma^{\prime}=5 \mathrm{kN} / \mathrm{m}^{3}$.

Application 1: In the first example, the material factor, $\gamma_{\mathrm{m}}$, which is defined as the partial safety factor applied to the soil shear strength (ISO, 2003), is evaluated for a foundation with 
given footprint area. Foundation geometry and factored loads are prescribed, as summarised in Table 2, and the calculated material factor is compared for the seabed with the surficial crust and the single layer seabed. For the foundation geometry adopted, neglecting the crust leads to inadequate capacity, with a material factor of 0.61 (so less than unity), while accounting for the surficial crust explicitly increases the material factor nearly threefold to 1.64. Figure 24 illustrates the loading conditions and corresponding 'failure' material factors. Different aspect ratios of failure envelopes for the 'crust' and 'no crust' cases are evident, reflecting the more significant benefit from the crust for sliding and torsion resistance, compared with vertical and moment resistance.

Application 2: The second example compares the minimum foundation footprint for a given material factor, aspect ratio and embedment ratio, as summarised in Table 3, and factored loads taken as those in Example 1 (Table 2). The results are summarised in Table 4 and show that for an embedment ratio $d / B=0.1$, giving $d / t_{c}=0.5$, the minimum plan area of the mudmat may double if the crust is neglected, despite the assumed higher mudline strength in recognition of neglecting the crust. A greater skirt depth, $d / B=0.15$, was also considered in this example. Contrary to the single layer soil profile, a larger foundation area is required for the deeper skirt because this is detrimental for the crust case due to the conservative assumption of smooth skirts. Even though the difference in required footprint area diminishes for the cases of 'crust' and 'no crust' as foundation level approaches the base of the crust, it is still significant. The examples shown here, while idealised, clearly illustrate the potential efficiencies in mudmat design if a surficial seabed crust is considered explicitly in estimating the foundation capacity.

\section{CONCLUSIONS}

The overall aim of this paper has been to quantify the effect of a surficial crust on the sixdegree-of-freedom capacity of rectangular mudmats for offshore deepwater developments. 
Algebraic expressions obtained from parametric studies are set out for predicting the loadcarrying capacities for mudmats under $\mathrm{V}-\mathrm{H}^{2}-\mathrm{M}^{2}-\mathrm{T}$ loading as a function of relative crust depth, skirt embedment and shear strength ratio of the upper crust and underlying soil layer. The approximating expressions are well-suited to implementation into an automated calculation tool enabling optimisation in terms of foundation geometry, soil strength characteristics or load components. Example applications are presented, illustrating the potential efficiencies of explicitly accounting for a stronger surficial crust on mudmat capacity under fully three-dimensional loading. Neglecting the contribution of the crust generally leads to greater mudmat dimensions.

\section{NOTATION LIST}

$\begin{array}{ll}A & \text { bearing area of mudmat foundation } \\ B & \text { foundation breadth } \\ d & \text { foundation embedment } \\ E & \text { Young's modulus } \\ H_{\mathrm{max}} & \text { maximum available horizontal resistance } \\ H_{\mathrm{x}}, H_{\mathrm{y}} & \text { horizontal load along x- and y- axis } \\ H_{\mathrm{xult}}, H_{\text {yult }} & \text { horizontal capacity along x- and y-axis } \\ k & \text { undrained shear strength gradient } \\ L & \text { foundation length } \\ M_{\mathrm{max}} & \text { maximum available over-turning resistance } \\ M_{\mathrm{x}}, M_{\mathrm{y}} & \text { moment about x- and y- axis } \\ M_{\mathrm{xult}}, M_{\mathrm{yult}} & \text { moment capacity about x- and y-axis } \\ N_{\mathrm{p}} & \text { skirt bearing factor } \\ S_{u} & \text { undrained shear strength } \\ S_{\mathrm{ubs}} & \text { undrained shear strength at the interface } \\ S_{\mathrm{ut}} & \text { undrained shear strength in the crust } \\ t_{\mathrm{c}} & \text { crust thickness } \\ T & \text { torsion } \\ T_{\mathrm{ult}} & \text { torsional capacity } \\ V & \text { vertical load } \\ V_{\mathrm{ult}} & \text { undrained vertical capacity } \\ \gamma^{\prime} & \text { soil effective unit weight } \\ \gamma_{m} & \text { material factor } \\ \theta & \text { direction of resultant horizontal load } \\ \theta_{\mathrm{m}} & \text { direction of resultant moment } \\ \kappa & \text { soil heterogeneity factor, (kB/subs) } \\ v & \text { Poisson's ratio } \\ & \end{array}$




\section{ACKNOWLEDGEMENTS}

This work forms part of the activities of the Centre for Offshore Foundation Systems (COFS), currently supported as a node of the Australian Research Council Centre of Excellence for Geotechnical Science and Engineering and as a Centre of Excellence by the Lloyd's Register Foundation. Lloyd's Register Foundation helps to protect life and property by supporting engineering-related education, public engagement and the application of research. Part of the research presented here derives from a collaboration between COFS, Subsea 7 and BP.

\section{REFERENCES}

Button, S. (1953) The bearing capacity of footings on a two-layer cohesive subsoil. In Proc. of the 3rd Int. Conf. Soil Mech. Found. Eng. Zurich, pp. 332-335.

Dassault Systèmes (2010) Abaqus analysis users' manual. Simulia Corp, Providence, RI, USA.

De Groot, D. J., Lunne, T. \& Tjelta, T. I. (2010) Recommended best practice for geotechnical site characterisation of cohesive offshore sediments. In Proc. of the $2^{\text {nd }}$ Int. Symp. on Front. in Offshore Geotech. (ISFOG 2010). Perth, Australia, pp. 33-57.

Ehlers, C., Chen, J., Roberts, H. \& Lee, Y. (2005) The origin of near-seafloor crust zones in deepwater. In Proc. of the $1^{\text {st }}$ Int. Symp. on Front. in Offshore Geotech. (ISFOG 2005). Perth, Australia, pp. 927-934.

Feng, X., Gourvenec, S. \& Randolph, M. (2014a) Optimal skirt spacing for subsea mudmats under loading in six degrees of freedom. Appl. Ocean Res. 48:10-20.

Feng, X., Randolph, M. F., Gourvenec, S. \& Wallerand, R. (2014b) Design approach for rectangular mudmats under fully three-dimensional loading. Géotechnique 64(1):5163.

Finnie, I. M. S. \& Morgan, N. (2004) Torsional loading of subsea structures. In Proc. of 14 ${ }^{\text {th }}$ Int. Offshore and Polar Eng. Conf. Toulon, France, pp. 326-333. 
Gourvenec, S (2007) Shape effects on the capacity of rectangular footings under general loading. Géotechnique 57(8):637-646.

Gourvenec, S. (2008) Effect of embedment on the undrained capacity of shallow foundations under general loading. Géotechnique 58(3):177-185.

Gourvenec, S. \& Randolph, M. (2003) Effect of strength non-homogeneity on the shape of failure envelopes for combined loading of strip and circular foundations on clay. Géotechnique 53(6):575-586.

Gourvenec, S., Randolph, M. \& Kingsnorth, O. (2006) Undrained bearing capacity of square and rectangular footings. Int. J. of Geomech. 6(3):147-157.

ISO (2003) ISO19901-4: Petroleum and natural gas industries -specific requirements for Offshore Structures - Part 4: Geotechnical and foundation design considerations $-1^{\text {st }}$ Edition. Geneva, Switzerland: International Organisation for Standardisation.

Kuo, M. \& Bolton, M. (2013) The nature and origin of deep ocean clay crust from the Gulf of Guinea. Géotechnique 63(6):500-509.

Kuo, M. \& Bolton, M. (2014) Shear tests on deep-ocean clay crust from the Gulf of Guinea. Géotechnique 64(4):249-257.

Merifield, R. \& Nguyen, V. (2006) Two-and three-dimensional bearing-capacity solutions for footings on two-layered clays. Geomech. Geoengin: An Int. J. 1(2):151-162.

Merifield, R., Sloan, S. \& Yu, H. (1999) Rigorous plasticity solutions for the bearing capacity of two-layered clays. Géotechnique 49(4):471-490.

Meyerhof, G. \& Hanna, A. (1978) Ultimate bearing capacity of foundations on layered soils under inclined load. Can. Geotech. J. 15(4):565-572.

Michalowski, R. L. (2002) Collapse loads over two-layer clay foundation soils. Soil. Found. 42(1):1-7.

Murff, J. D., Aubeny, C. P. \& Yang, M. (2010) The effect of torsion on the sliding resistance of rectangular foundations. In Proc. of $2^{\text {nd }}$ Int. Symp. on Front. in Offshore Geotech. 
(ISFOG 2010). Perth, Australia, pp. 439-443.

Park, H., Lee, S. R. \& Jee, S. H. (2010) Bearing capacity of surface footing on soft clay underlying stiff nonhomogeneous Desiccated Crust. Int. J. Offshore. Polar. Eng. 20(03):224-232.

Stewart, D. \& Randolph, M. (1994) T-bar penetration testing in soft clay. J. Geotech. Eng. ASCE 120(12):2230-2235.

Tan, F. S. (1990) Centrifuge and theoretical modelling of conical footings on sand. $\mathrm{PhD}$ thesis, University of Cambridge.

Yu, L., Liu, J., Kong, X. \& Hu, Y. (2011) Three-dimensional large deformation FE analysis of square footings in two-layered clays. J. Geotech. Geoenviron. Eng. ASCE 137(1):52-58.

Zhu, M. \& Michalowski, R. L. (2005) Bearing capacity of rectangular footings on two-layer clay. In Proc. of $16^{\text {th }}$ Int. Conf. on Soil Mech. and Geotech. Eng.: Geotechnology in Harmony with the Global Environment. Osaka, Japan, pp. 997-1000. 


\section{TABLES}

Table 1 Principal design process for mudmats in single layered soil

1 Evaluate ultimate uniaxial capacities for vertical $\left(\mathrm{V}_{\text {ult }}\right)$, horizontal $\left(\mathrm{H}_{\mathrm{x}(\mathrm{y}), \mathrm{ult}}\right)$, moment $\left(\mathrm{M}_{\mathrm{x}(\mathrm{y}) \text {,ult }}\right)$ and torsional $\left(\mathrm{T}_{\text {ult }}\right)$ loading

2 Reduce ultimate horizontal, moment and torsional capacity to maximum values available associated with the mobilised (design) vertical capacity, $\mathrm{v}=\mathrm{V} / \mathrm{V}_{\text {ult }}$

3 For given angle, $\theta$, of resultant horizontal load, $H$, in the horizontal plane, evaluate the corresponding ultimate horizontal capacity, and similarly for ultimate moment capacity associated with $\theta_{\mathrm{m}}$ in $\mathrm{M}_{\mathrm{x}}-\mathrm{M}_{\mathrm{y}}$ loading plane

4 Evaluate the reduced ultimate horizontal and moment capacities due to the mobilised torsion, $\mathrm{t}=$ $\mathrm{T} / \mathrm{T}_{\text {ult }}$

Table 2 Input for example application 1

\begin{tabular}{llll}
\hline Parameter & Values & Parameter & Values \\
\hline Width, B: m & 5 & Vertical load, V: kN & 400 \\
Length, L: $\mathrm{m}$ & 10 & Horizontal load, $\mathrm{H}_{\mathrm{x}}: \mathrm{kN}$ & 130 \\
Skirt depth, d: $\mathrm{m}$ & 0.5 & Horizontal load, $\mathrm{H}_{\mathrm{y}}: \mathrm{kN}$ & 130 \\
Aspect ratio, B/L & 0.5 & Moment, $\mathrm{M}_{\mathrm{x}}: \mathrm{kNm}$ & 390 \\
Embedment ratio, d/B & 0.1 & Moment, $\mathrm{M}_{\mathrm{y}}: \mathrm{kNm}$ & -520 \\
Skirt friction factor: $\alpha_{\text {skirt }}$ & 0 & Torsion, $\mathrm{T}: \mathrm{kNm}$ & 520 \\
\hline
\end{tabular}

Table 3 Input for example application 2

\begin{tabular}{ll}
\hline Parameter & Values \\
\hline Aspect ratio, B/L & 0.5 \\
Embedment ratio, d/B & $0.1 \& 0.15$ \\
Material factor, $\gamma_{\mathrm{m}}$ & 1.5 \\
\hline Loads as in example application 1,Table 2 \\
\hline
\end{tabular}

Table 4 Predicted minimum foundation footprint from example application 2

\begin{tabular}{lllll}
\hline & \multicolumn{3}{c}{$\mathrm{d} / \mathrm{B}=0.1$} & \multicolumn{2}{c}{$\mathrm{d} / \mathrm{B}=0.15$} \\
\hline & Crust $\left(\mathrm{t}_{\mathrm{c}} / \mathrm{B}=0.2\right)$ & No crust & Crust $\left(\mathrm{t}_{\mathrm{c}} / \mathrm{B}=0.2\right)$ & No crust \\
Width, B: $\mathrm{m}$ & 4.75 & 7.00 & 5.28 & 6.42 \\
Bearing Area, A: $\mathrm{m}^{2}$ & 45.1 & 98.1 & 55.7 & 82.4 \\
\hline
\end{tabular}




\section{FIGURE CAPTIONS}

Figure 1 Evidence of surficial crust zone based on in situ investigations

Figure 2 General loading for a rectangular mudmat and soil strength profile

Figure 3 Example failure envelopes of a mudmat on a single layer soil under $\mathrm{V}-\mathrm{H}^{2}-\mathrm{M}^{2}-\mathrm{T}$ loading

Figure 4 FE mesh for rectangular mudmats

Figure 5 Validation: Vertical bearing capacity of foundations on two-layer soil

Figure 6 Vertical bearing capacity

Figure 7 Moment capacity about y-axis

Figure 8 Moment capacity about $\mathrm{x}$-axis

Figure 9 Soil failure mechanisms for a mudmat under horizontal load $\left(d / t_{c}=0.5 ; t_{c} / B=0.2\right)$

Figure 10 Horizontal capacity along $\mathrm{x}$-axis

Figure 11 Horizontal capacity along y-axis

Figure 12 Torsional capacity

Figure 13 Finite element results and estimation for $\mathrm{V}-\mathrm{H}$ failure envelopes: $\mathrm{t}_{\mathrm{c}} / \mathrm{B}=0.2$

Figure 14 Finite element results and estimation for $V-M$ failure envelopes: $t_{\mathrm{c}} / \mathrm{B}=0.2$

Figure 15 Finite element results and estimation for $V$-T failure envelopes: $t_{c} / B=0.2$

Figure 16 Resultant horizontal and moment loading

Figure 17 Failure envelopes for biaxial horizontal loading

Figure 18 Failure envelopes for biaxial moment loading

Figure 19 Effects of direction of horizontal loads on normalised $\mathrm{H}-\mathrm{T}$ failure envelopes: $\mathrm{t}_{\mathrm{c}} / \mathrm{B}=$ 0.2

Figure 20 Effects of foundation embedment on normalised $H$-T failure envelopes: $t_{c} / B=0.2$

Figure 21 Normalised M-T failure envelopes

Figure 22 Normalised $\mathrm{H}_{\mathrm{x}}-\mathrm{M}_{\mathrm{y}}$ failure envelopes

Figure 23 Normalised $\mathrm{H}_{\mathrm{y}}-\mathrm{M}_{\mathrm{x}}$ failure envelopes

Figure 24 Example showing the effects of torsion on normalise $\mathrm{H}-\mathrm{M}$ failure envelopes: $\mathrm{subs} / \mathrm{s}_{\mathrm{ut}}$ $=0.6 ; \mathrm{d} / \mathrm{t}_{\mathrm{c}}=0.5 ; \mathrm{t}_{\mathrm{c}} / \mathrm{B}=0.2$

Figure 25 Loading conditions and failure envelopes for example application 1 


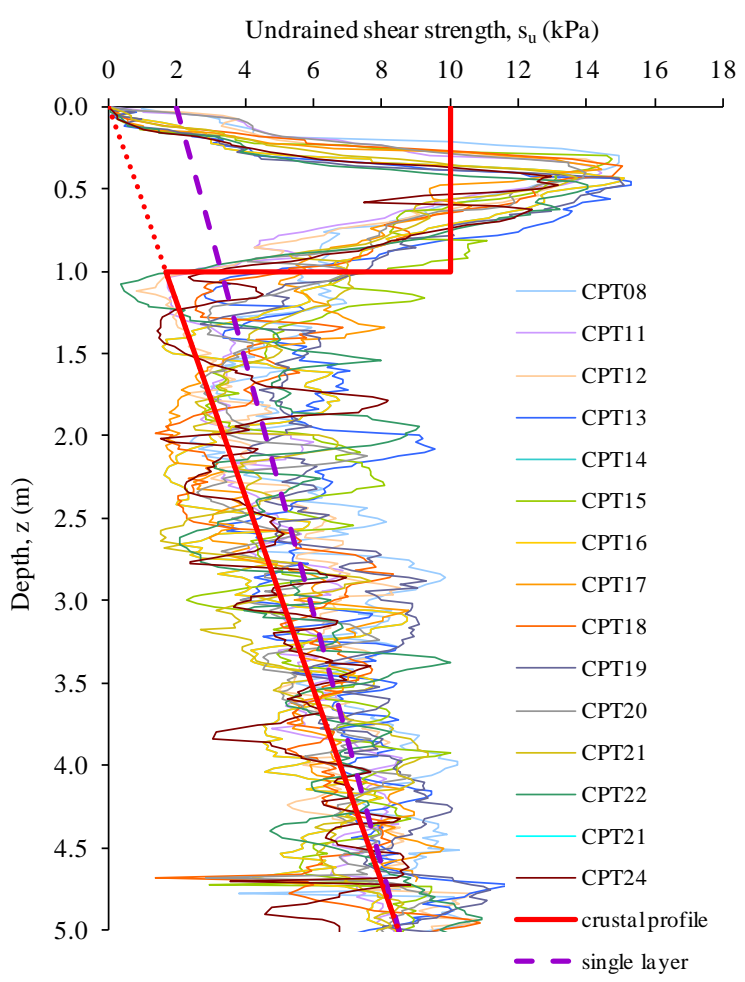

a) Confidential site location (figure courtesy of Subsea 7)

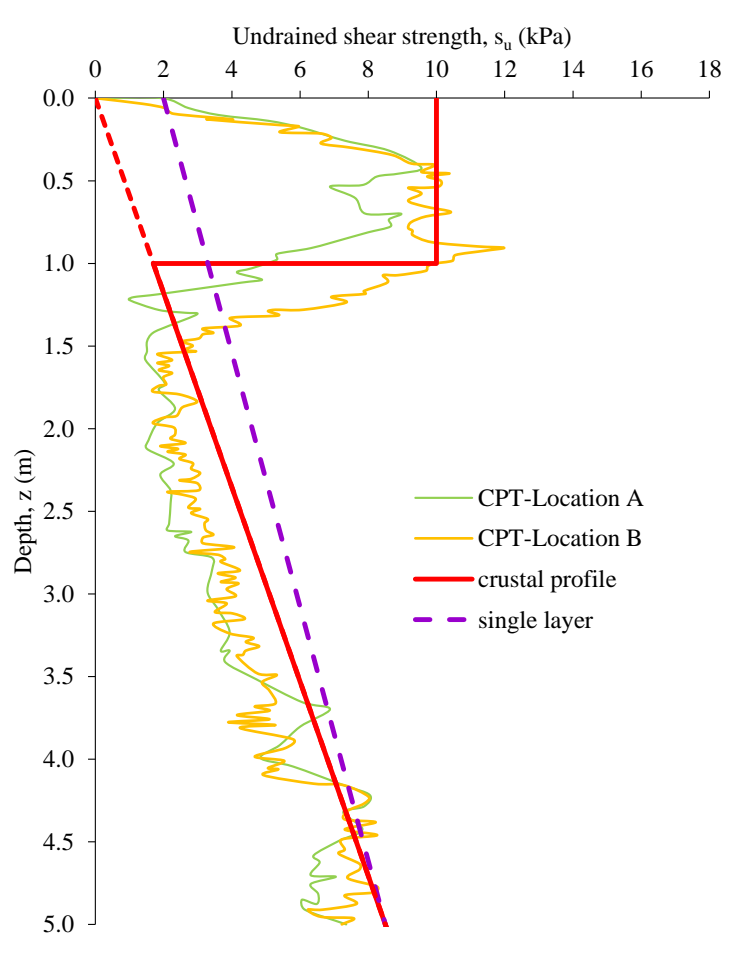

b) Deepwater offshore Nigeria (after Ehlers, et al., 2005)

Figure 1 Evidence of surficial crust zone based on in situ investigations

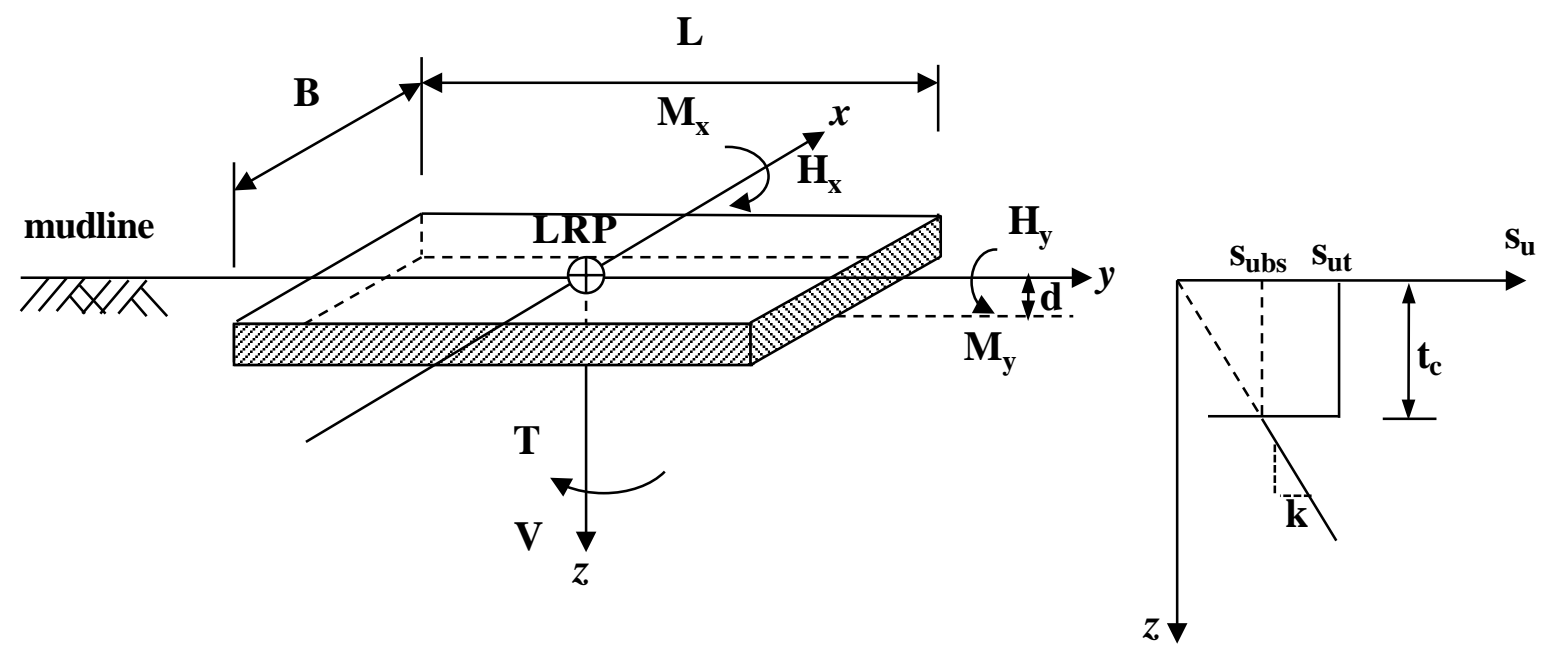

Figure 2 General loading for a rectangular mudmat and soil strength profile 


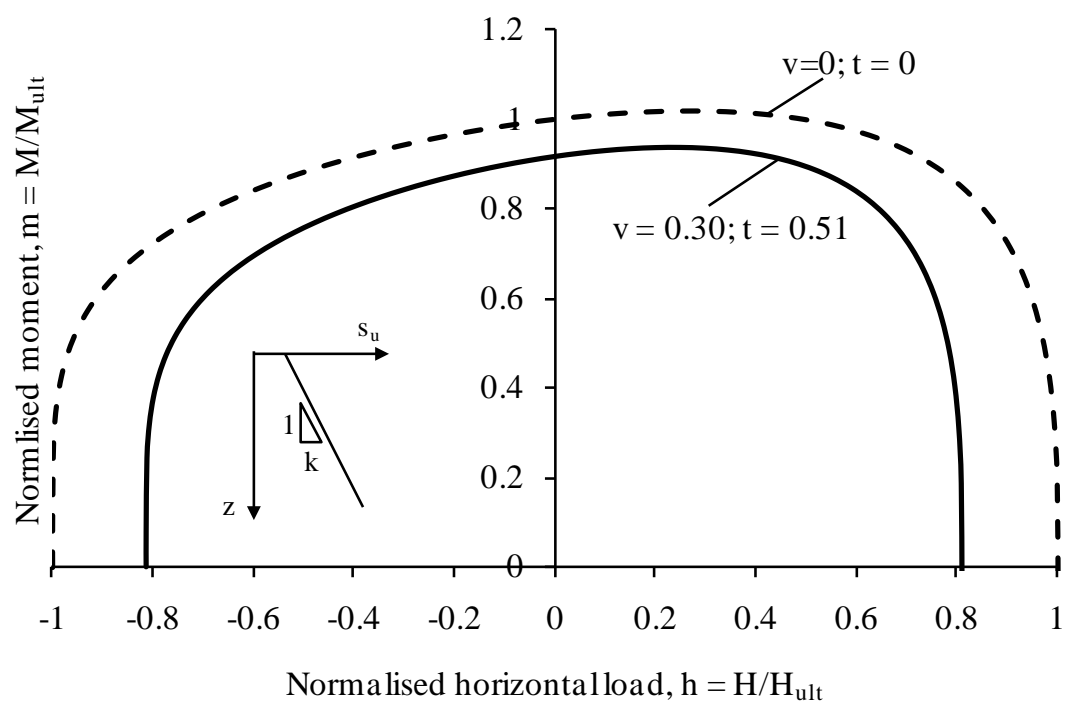

Figure 3 Example failure envelopes of a mudmat on a single layer soil under $\mathrm{V}-\mathrm{H}^{2}-\mathrm{M}^{2}-\mathrm{T}$ loading

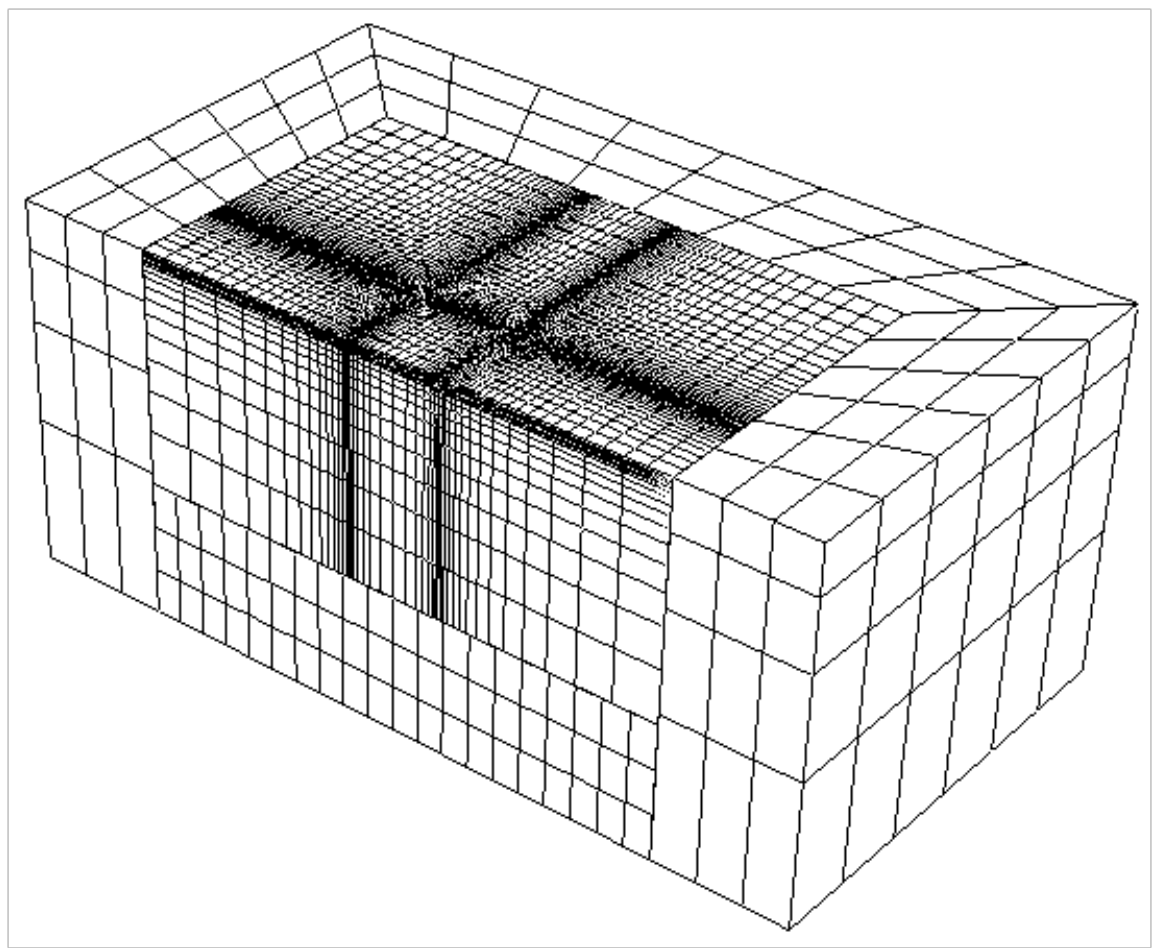

Figure 4 FE mesh for rectangular mudmats 


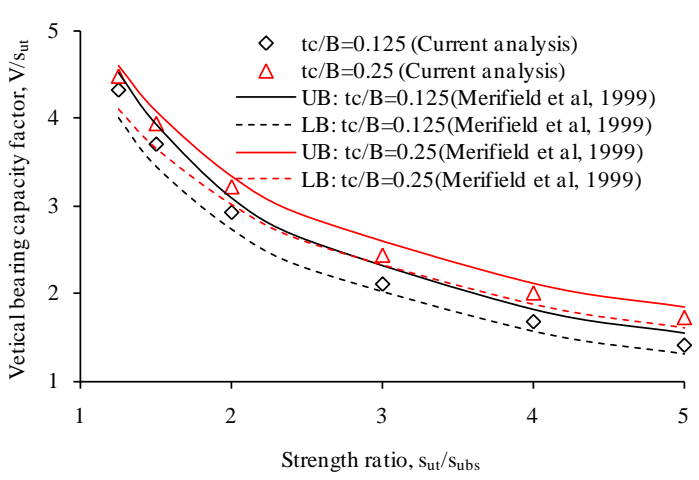

a) Strip foundations

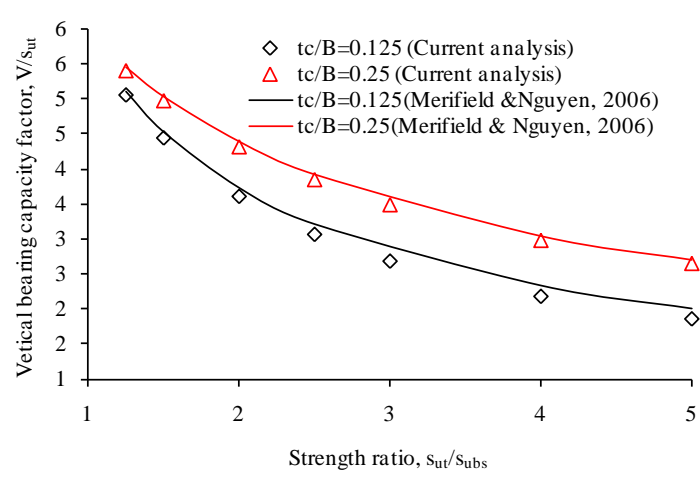

b) Square foundations

Figure 5 Validation: Vertical bearing capacity of foundations on two-layer soil

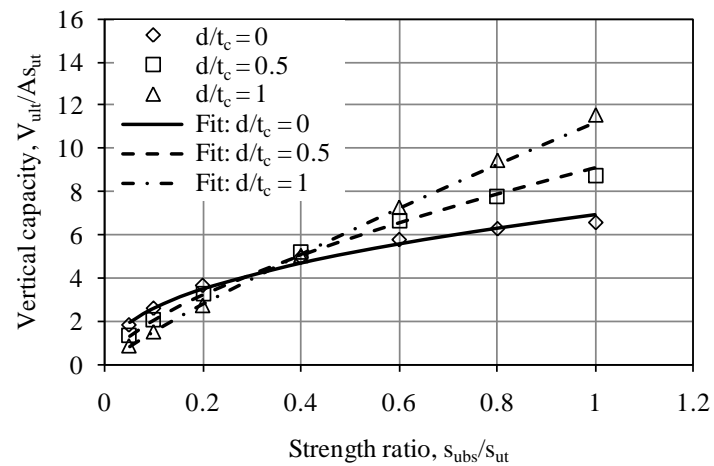

a) $t_{c} / B=0.2$

Figure 6 Vertical bearing capacity

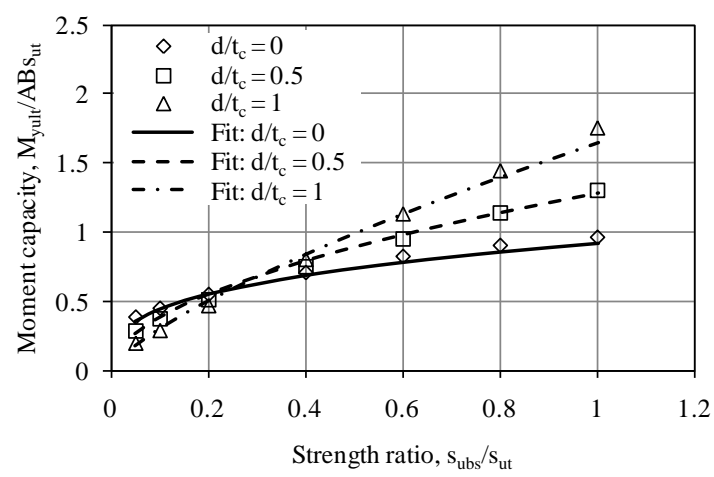
a) $t_{c} / B=0.2$
b) $t_{c} / B=0.1$

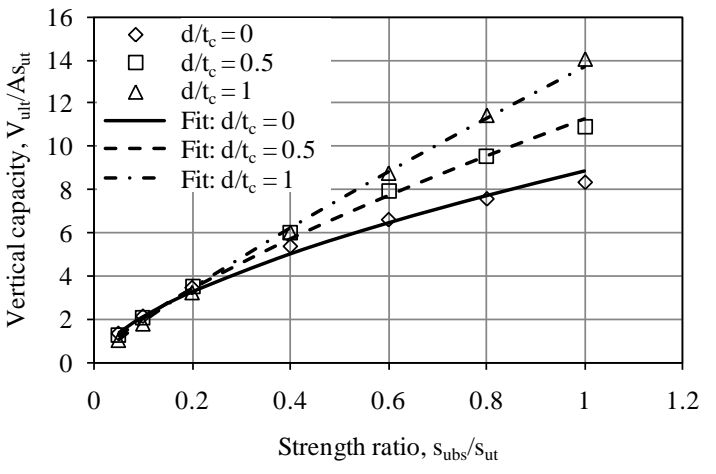

b) $t_{c} / B=0.1$

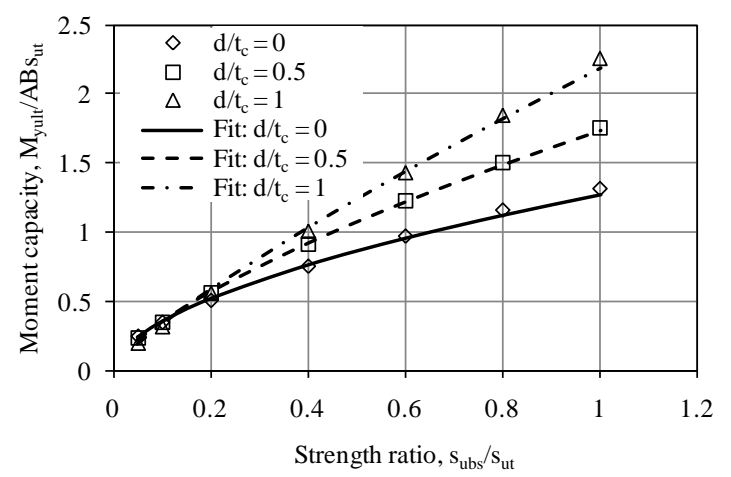

Figure 7 Moment capacity about y-axis 


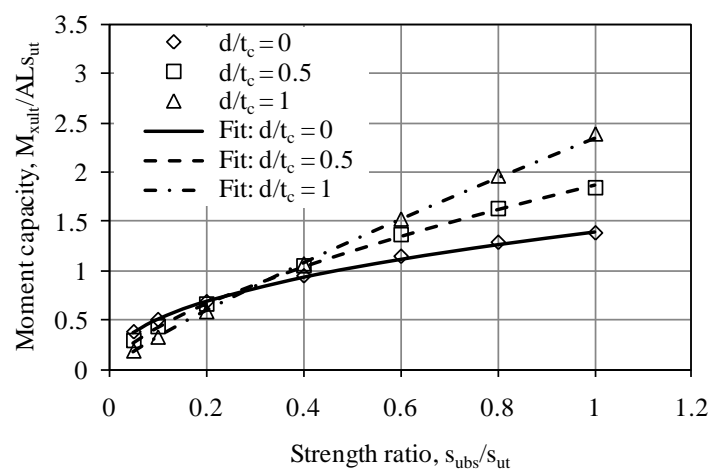

a) $t_{c} / B=0.2$

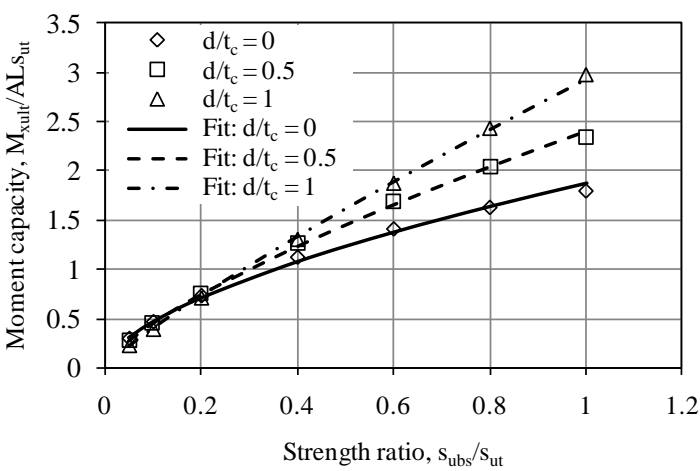

b) $t_{c} / B=0.1$

Figure 8 Moment capacity about x-axis

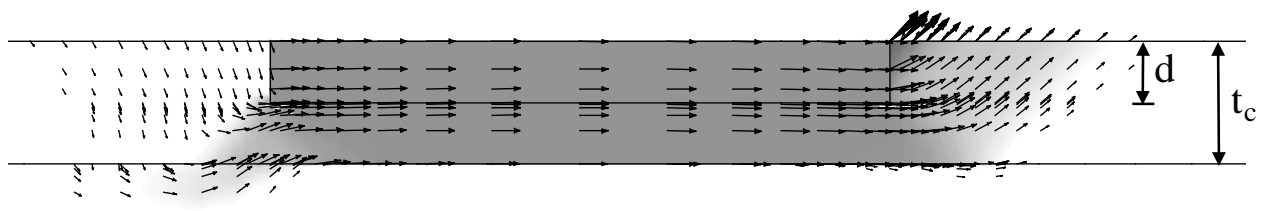

a) $\mathrm{S}_{\mathrm{ubs}} / \mathrm{s}_{\mathrm{ut}}=0.05$ : failure beneath the crust

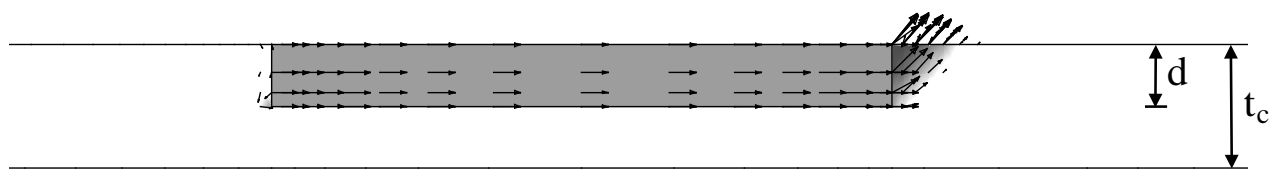

b) $\mathrm{S}_{\mathrm{ubs}} / \mathrm{S}_{\mathrm{ut}}=0.8$ : failure within the crust

Figure 9 Soil failure mechanisms for a mudmat under horizontal load $\left(d / t_{c}=0.5 ; t_{c} / B=0.2\right)$

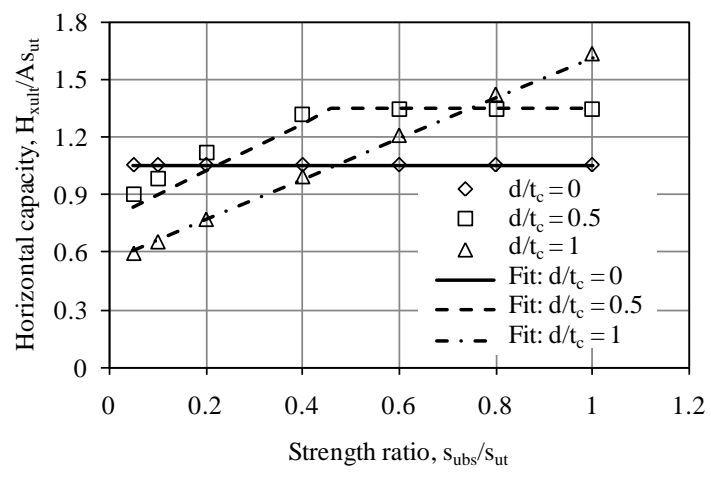

a) $t_{c} / B=0.2$

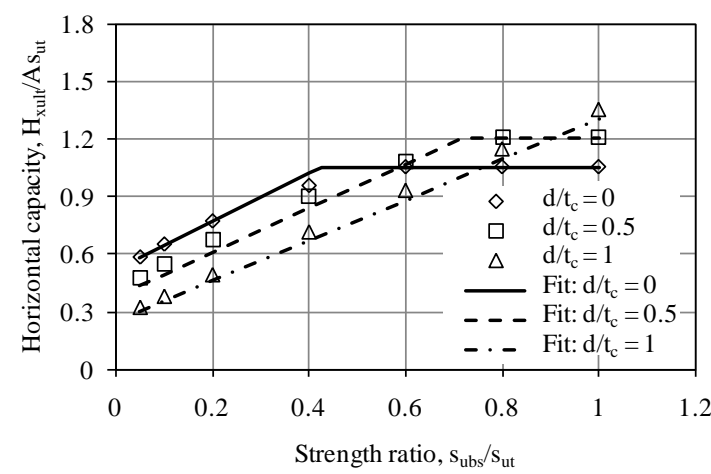

b) $t_{c} / B=0.1$

Figure 10 Horizontal capacity along x-axis 


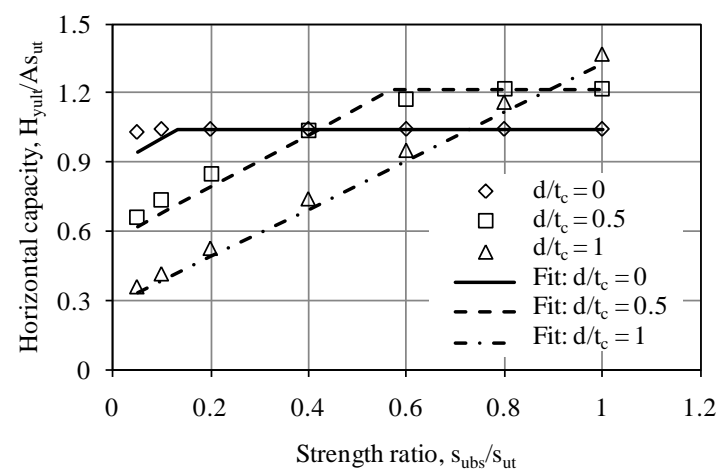

a) $t_{c} / B=0.2$

Figure 11 Horizontal capacity along y-axis

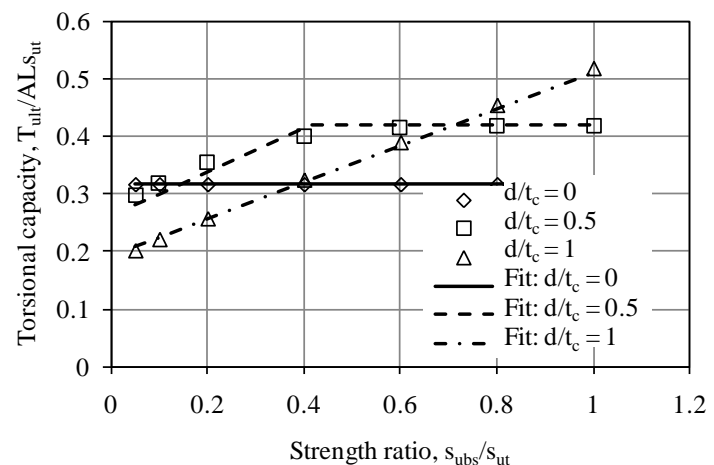

a) $t_{c} / B=0.2$

Figure 12 Torsional capacity

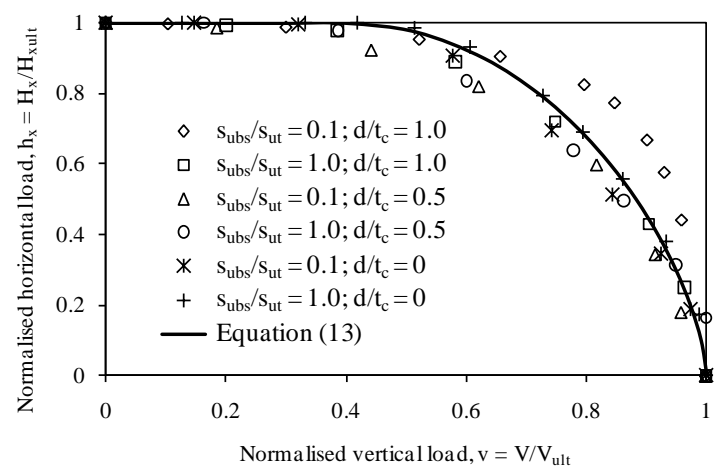

a) V-H failure envelope $\left(\theta=0^{\circ}\right)$

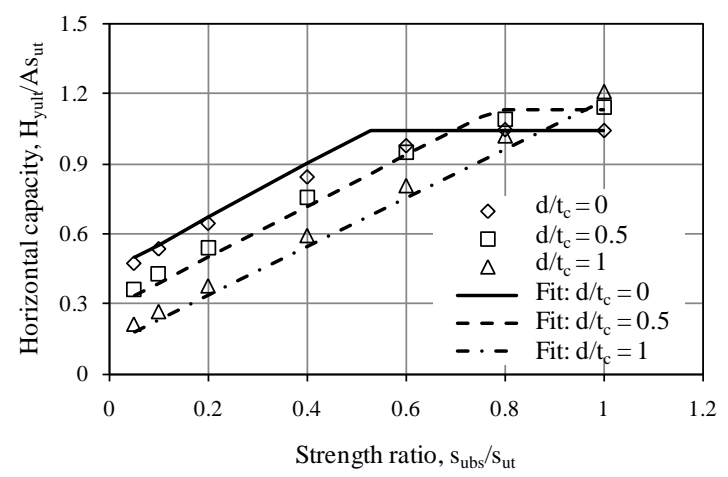

b) $t_{c} / B=0.1$

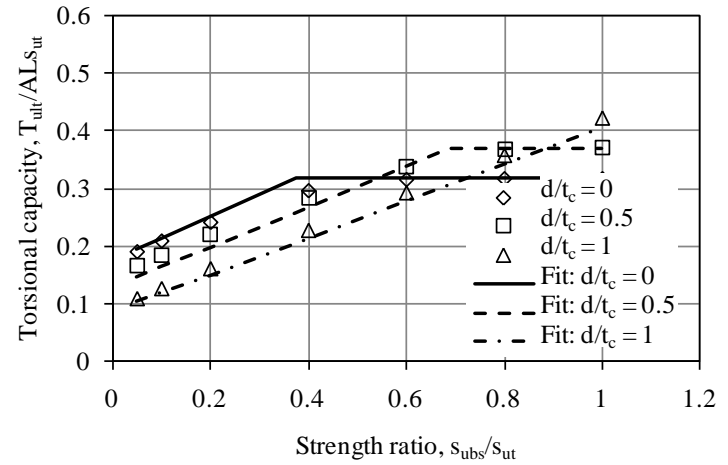

b) $t_{c} / B=0.1$

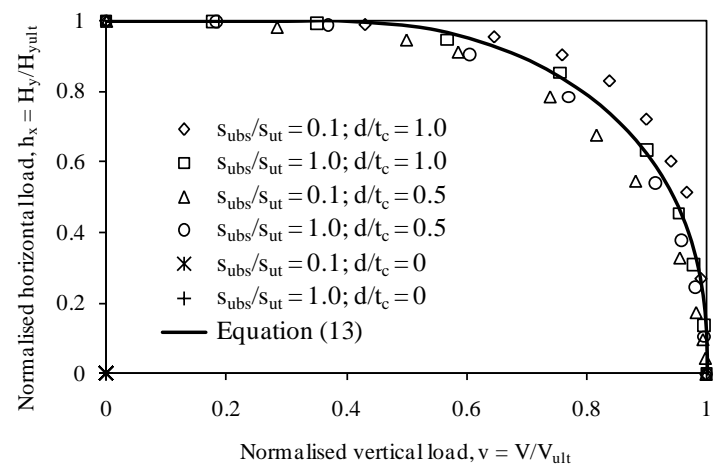

b) $\mathrm{V}$-H failure envelope $\left(\theta=90^{\circ}\right)$

Figure 13 Finite element results and estimation for $\mathrm{V}-\mathrm{H}$ failure envelopes: $\mathrm{t}_{\mathrm{c}} / \mathrm{B}=0.2$ 


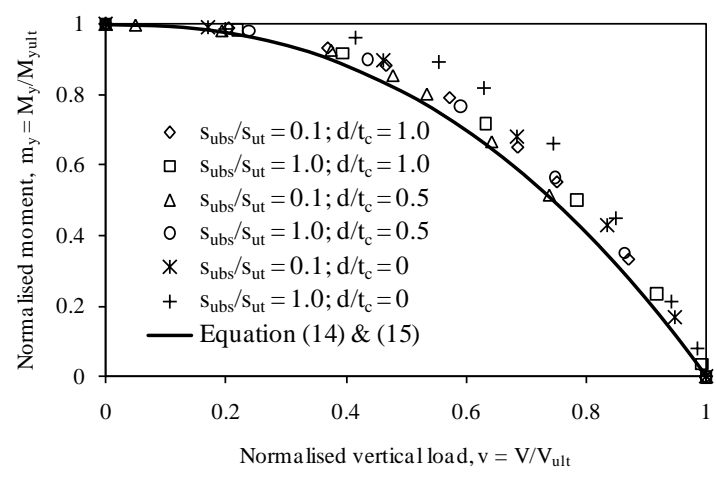

a) V-My plane (rotation about y-axis)

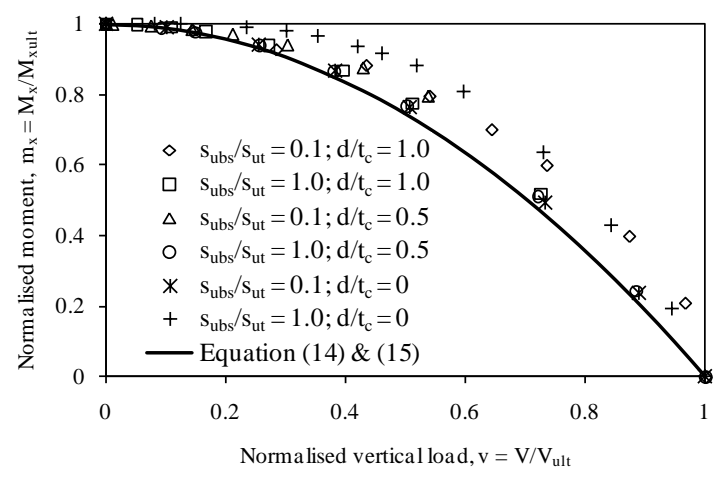

b) $\mathrm{V}-\mathrm{M}_{\mathrm{x}}$ plane (rotation about $\mathrm{x}$-axis)

Figure 14 Finite element results and estimation for $V-M$ failure envelopes: $t_{c} / B=0.2$

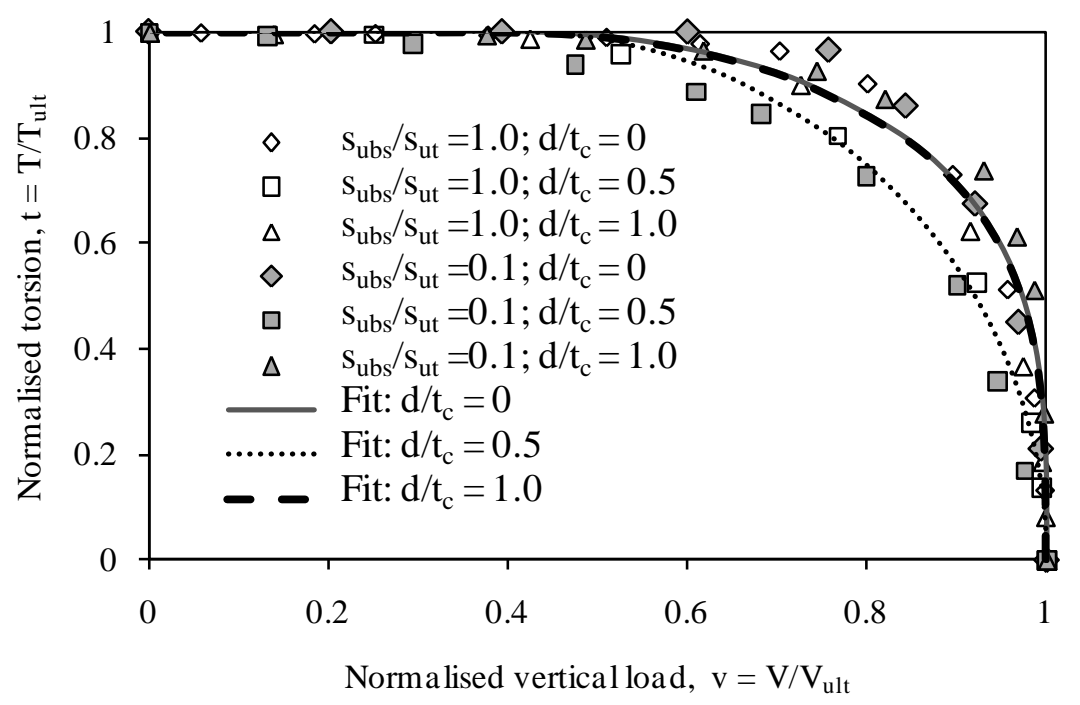

Figure 15 Finite element results and estimation for $V$-T failure envelopes: $t_{c} / B=0.2$

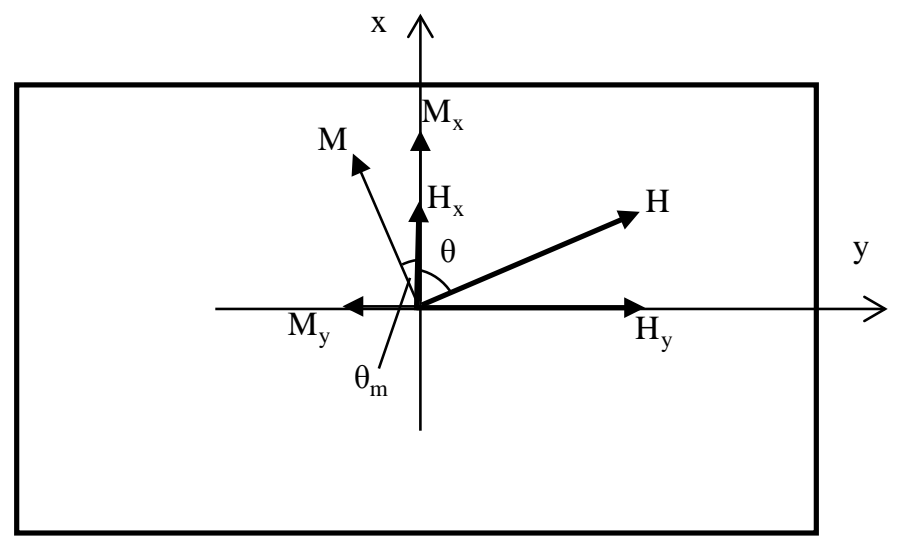

Figure 16 Resultant horizontal and moment loading 


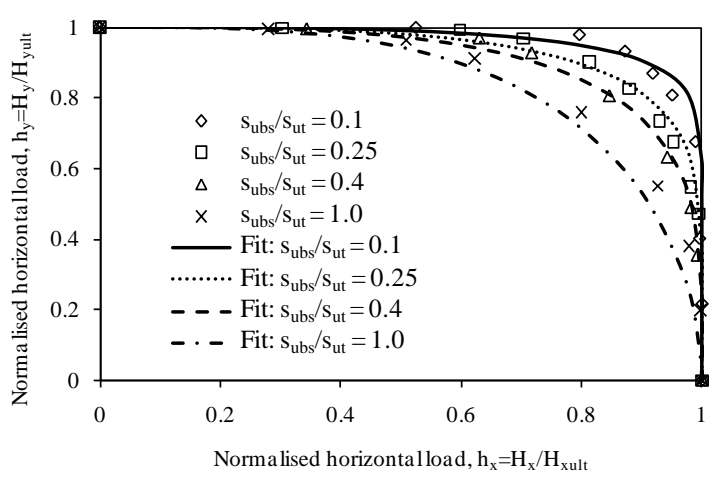

a) $t_{c} / B=0.2 ; d / t_{c}=1$

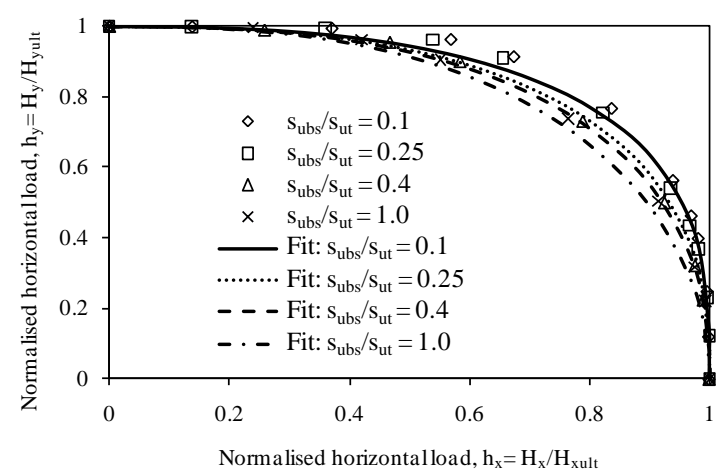

b) $t_{c} / B=0.2 ; d / t_{c}=0.5$

Figure 17 Failure envelopes for biaxial horizontal loading

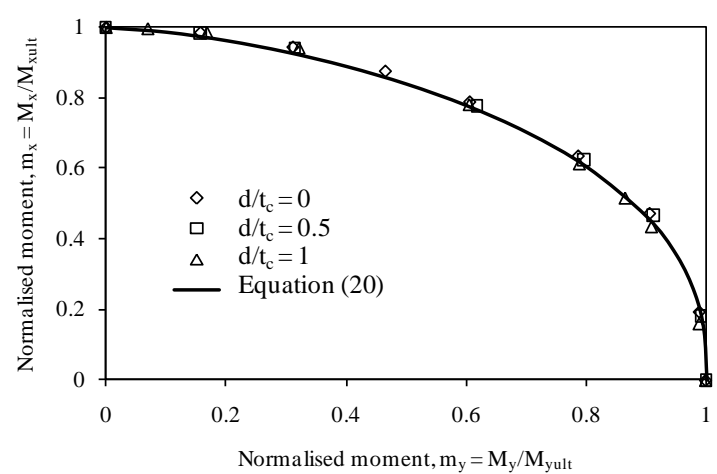

a) $t_{\mathrm{c}} / \mathrm{B}=0.2 ; \mathrm{kB} / \mathrm{s}_{\mathrm{ut}}=5$

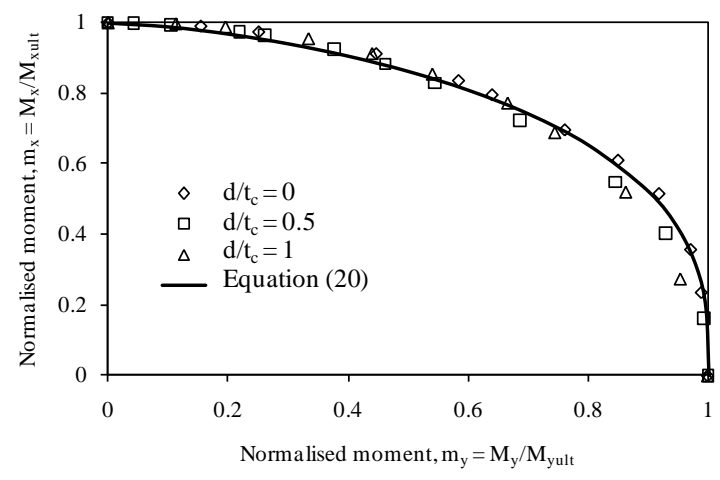

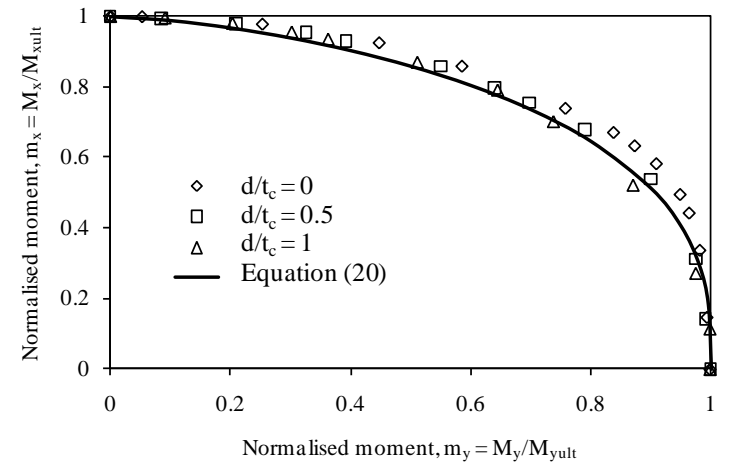

b) $\mathrm{t}_{\mathrm{c}} / \mathrm{B}=0.2 ; \mathrm{kB} / \mathrm{s}_{\mathrm{ut}}=1.25$

c) $\mathrm{t}_{\mathrm{c}} / \mathrm{B}=0.2 ; \mathrm{kB} / \mathrm{s}_{\mathrm{ut}}=0.5$

Figure 18 Failure envelopes for biaxial moment loading 


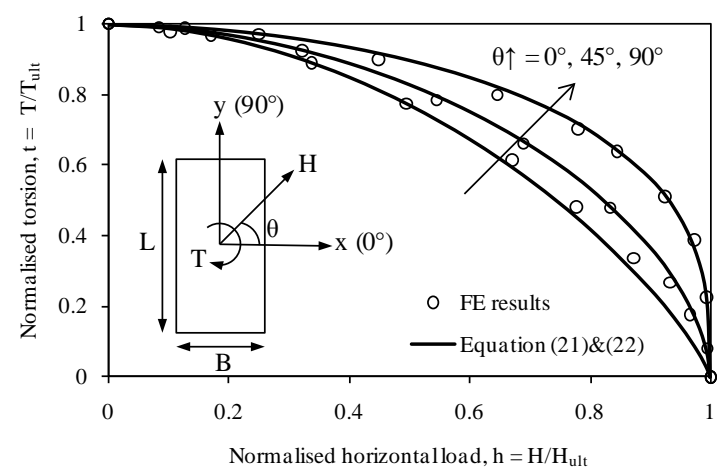

a) $d / t_{c}=0.5 ; s_{u b s} / s_{u t}=0.1$

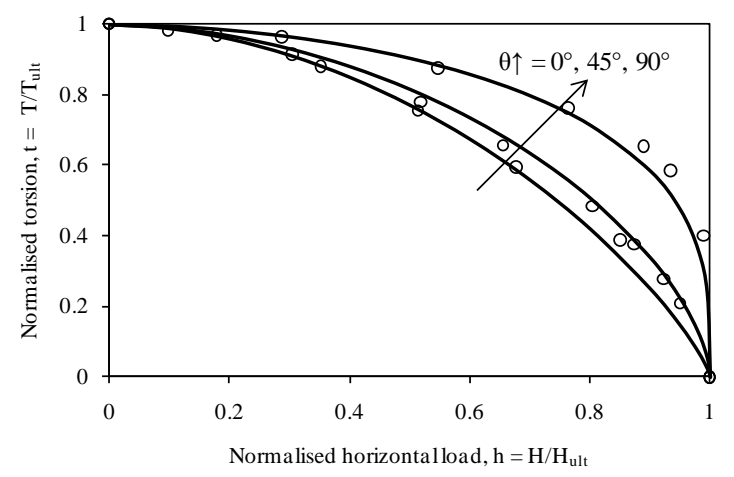

b) $\mathrm{d} / \mathrm{t}_{\mathrm{c}}=1.0 ; \mathrm{s}_{\mathrm{ubs}} / \mathrm{s}_{\mathrm{ut}}=0.4$

Figure 19 Effects of direction of horizontal loads on normalised H-T failure envelopes: $t_{c} / B=$ 0.2
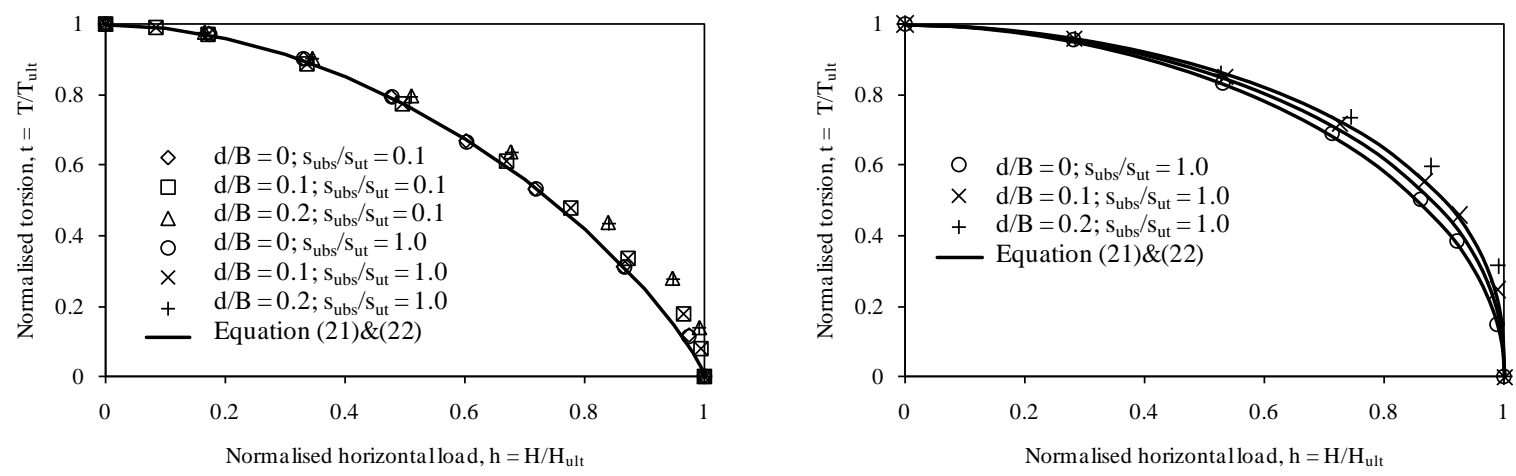

a) $\theta=0^{\circ}$

b) $\theta=90^{\circ}$; $\mathrm{s}_{\mathrm{ubs}} / \mathrm{s}_{\mathrm{ut}}=1$

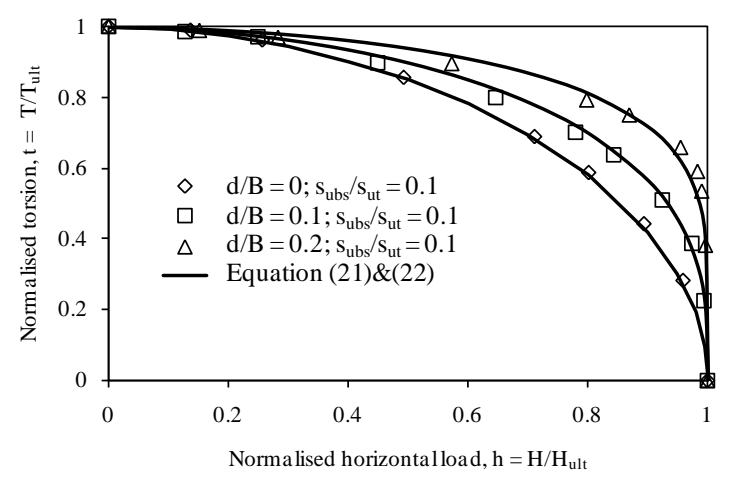

c) $\theta=90^{\circ} ; \mathrm{s}_{\mathrm{ubs}} / \mathrm{s}_{\mathrm{ut}}=0.1$

Figure 20 Effects of foundation embedment on normalised $H$-T failure envelopes: $t_{c} / B=0.2$ 


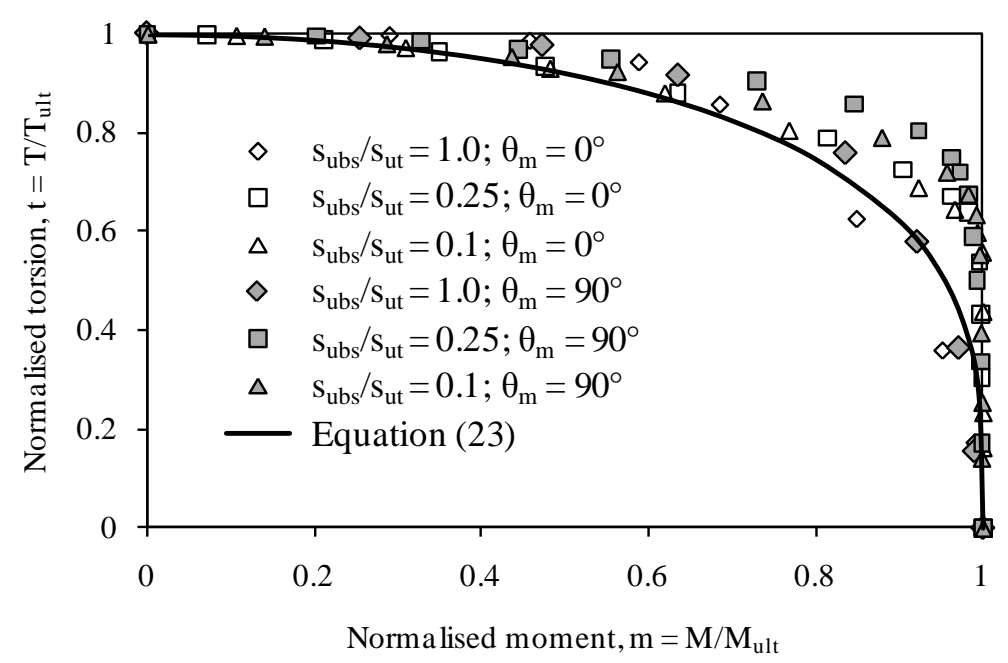

a) $t_{c} / B=0.2 ; d / t_{c}=0$

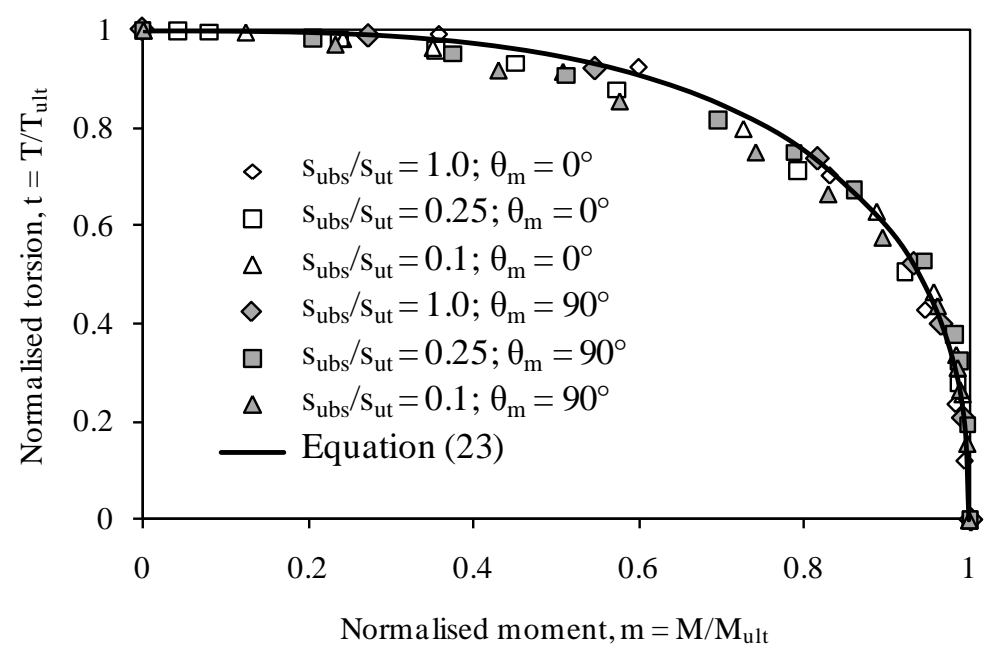

b) $t_{c} / B=0.2 ; d / t_{c}=0.5$

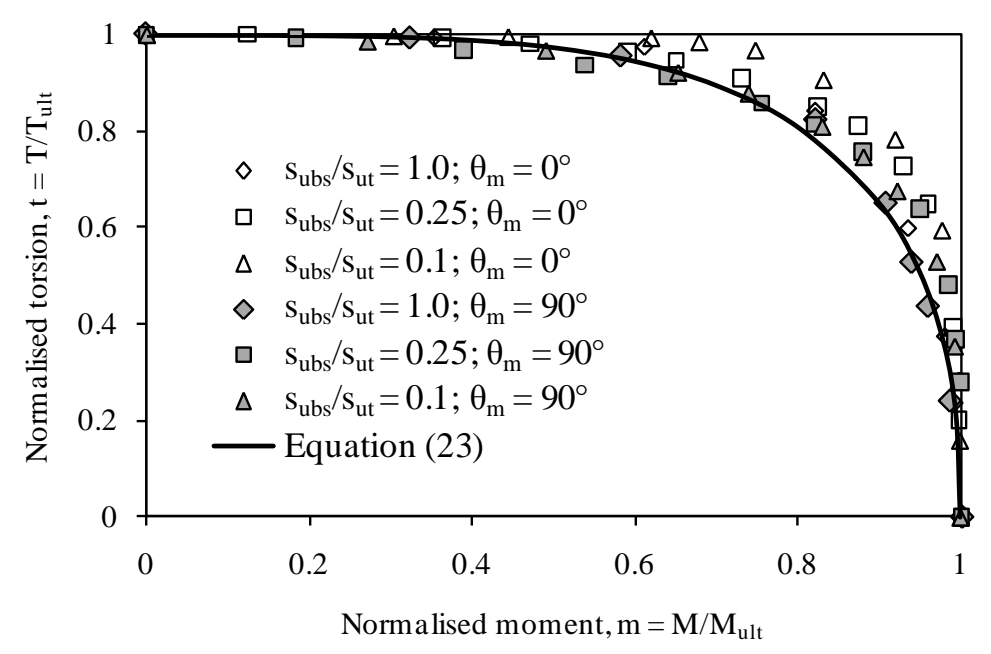

c) $t_{c} / B=0.2 ; d / t_{c}=1$

Figure 21 Normalised M-T failure envelopes 


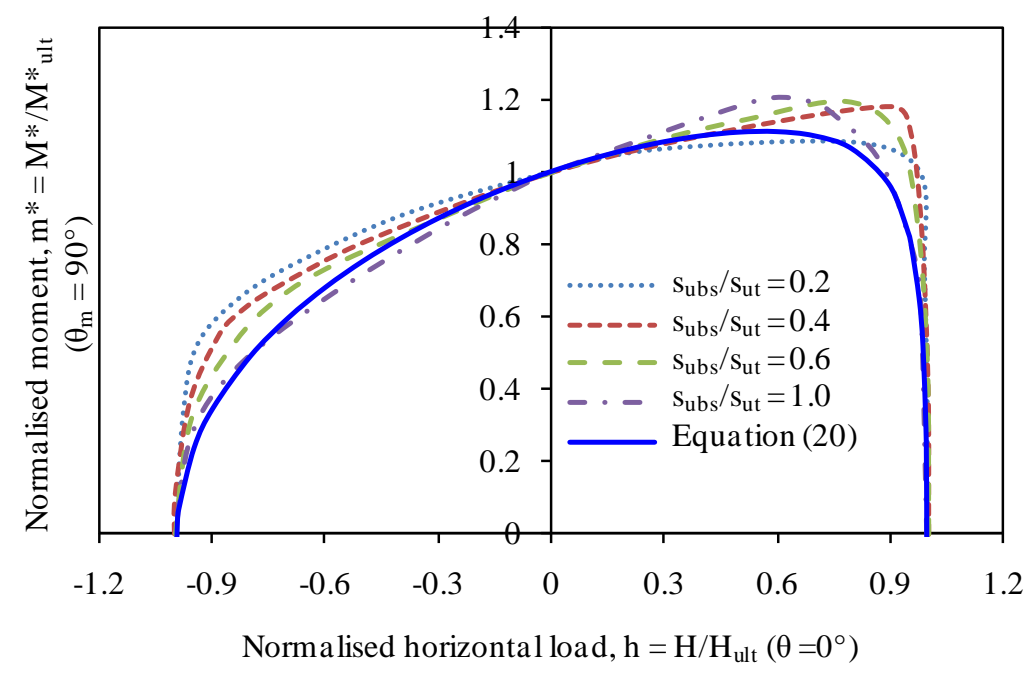

a) $t_{c} / B=0.2 ; d / t_{c}=0$

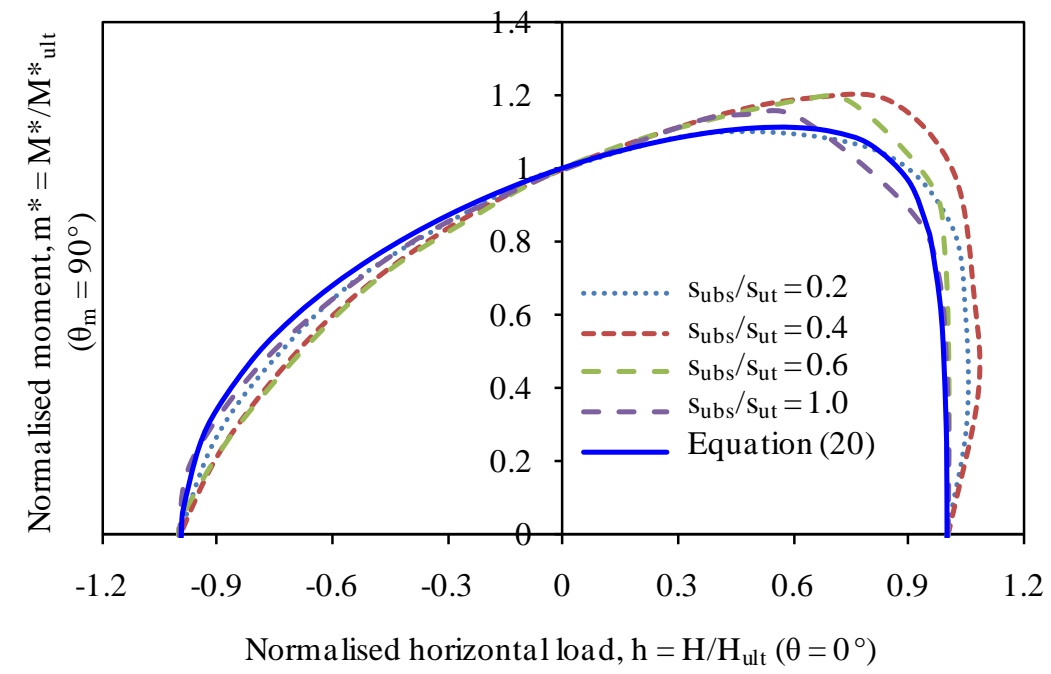

b) $\mathrm{t}_{\mathrm{c}} / \mathrm{B}=0.2 ; \mathrm{d} / \mathrm{t}_{\mathrm{c}}=0.5$

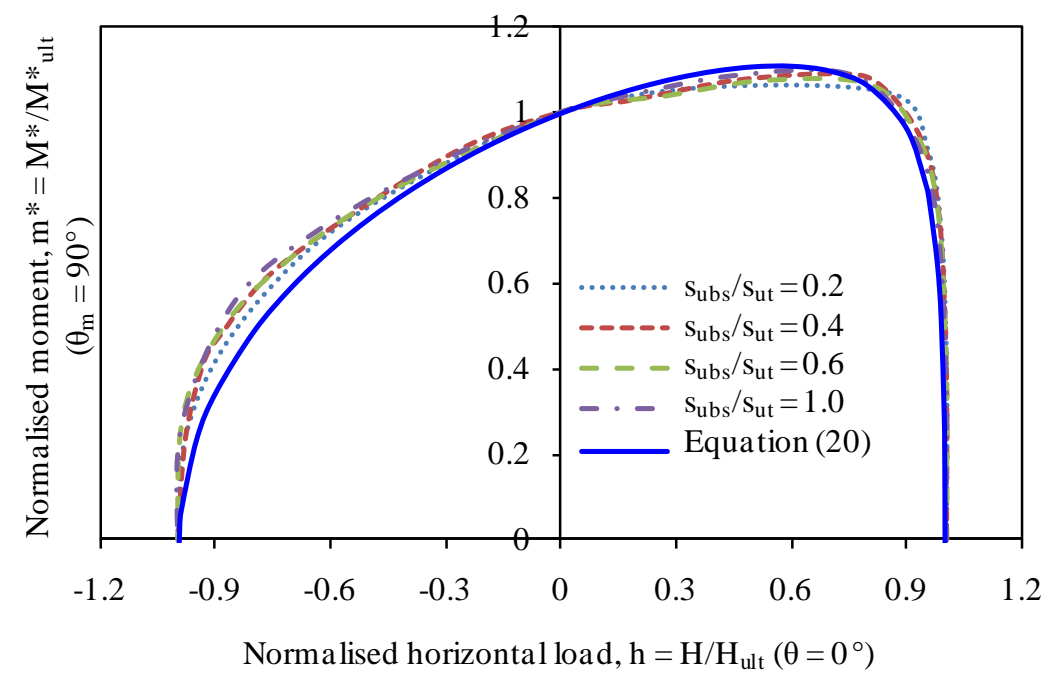

c) $\mathrm{t}_{\mathrm{c}} / \mathrm{B}=0.2 ; \mathrm{d} / \mathrm{t}_{\mathrm{c}}=1$

Figure 22 Normalised $\mathrm{H}_{\mathrm{x}}-\mathrm{M}_{\mathrm{y}}$ failure envelopes 


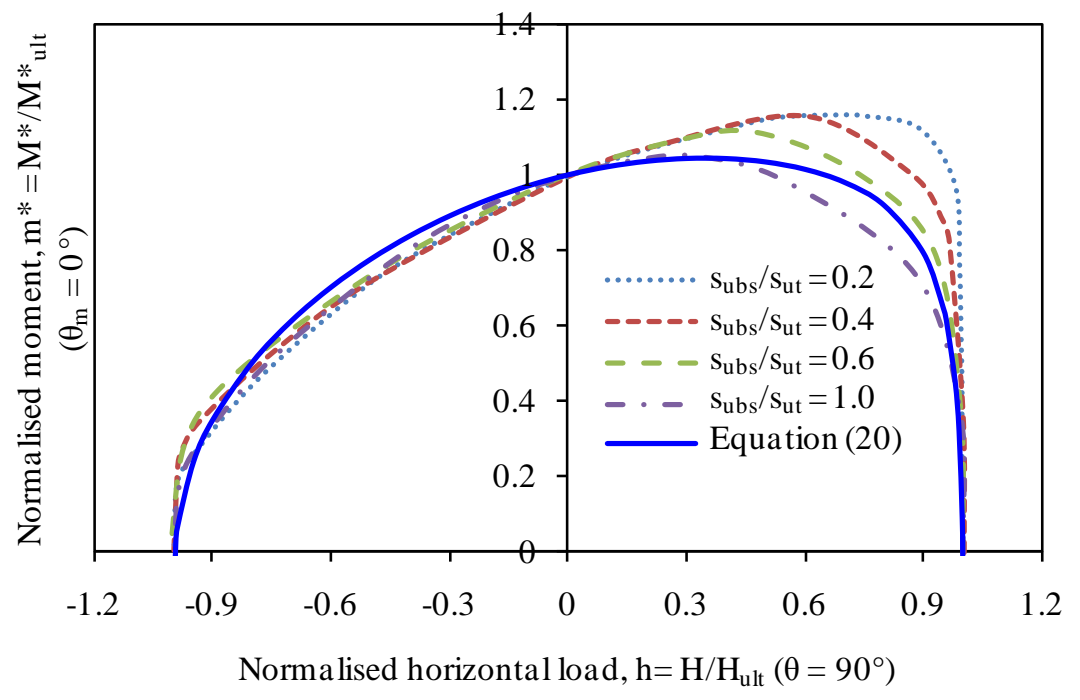

a) $t_{\mathrm{c}} / \mathrm{B}=0.2 ; \mathrm{d} / \mathrm{t}_{\mathrm{c}}=0$

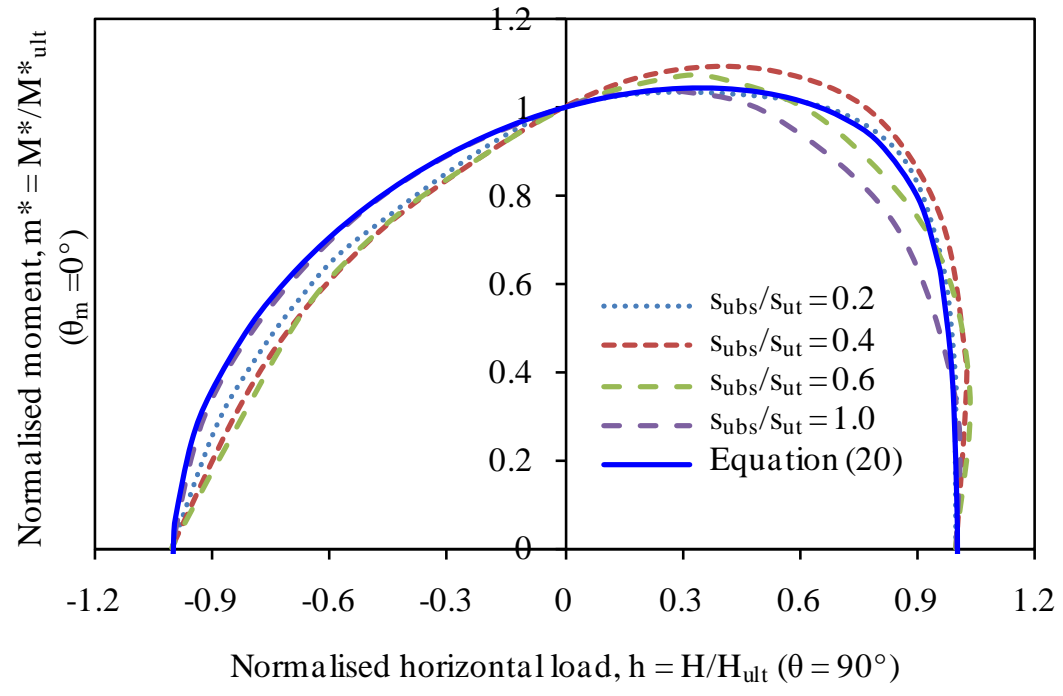

b) $\mathrm{t}_{\mathrm{c}} / \mathrm{B}=0.2 ; \mathrm{d} / \mathrm{t}_{\mathrm{c}}=0.5$

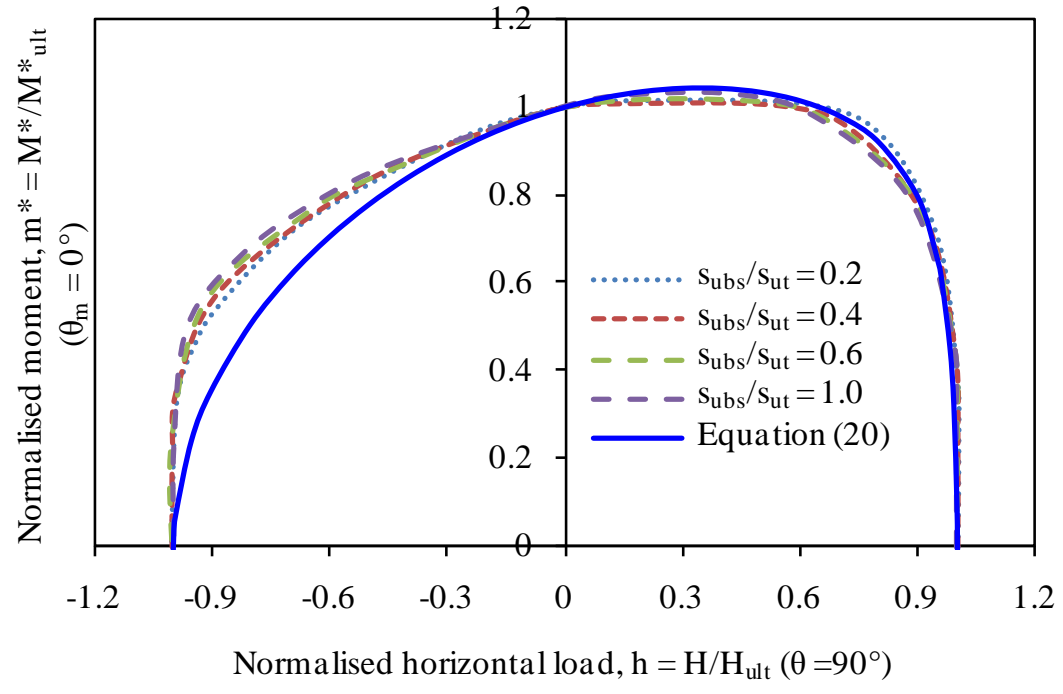

c) $\mathrm{t}_{\mathrm{c}} / \mathrm{B}=0.2 ; \mathrm{d} / \mathrm{t}_{\mathrm{c}}=1$

Figure 23 Normalised $\mathrm{H}_{\mathrm{y}}-\mathrm{M}_{\mathrm{x}}$ failure envelopes 


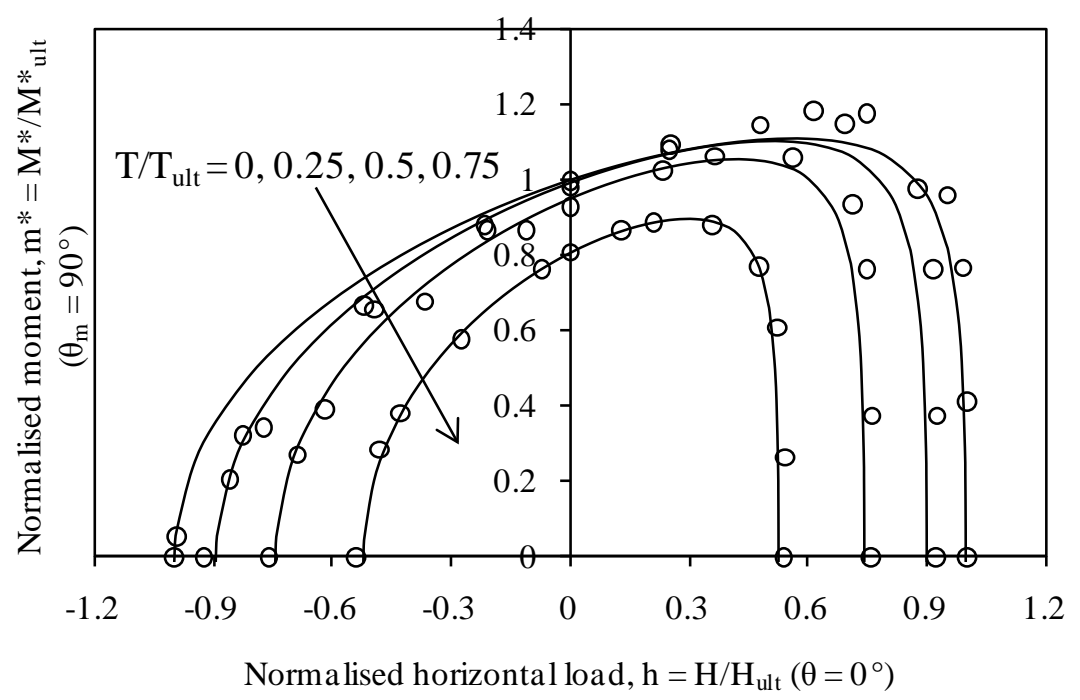

Figure 24 Example showing the effects of torsion on normalise $\mathrm{H}-\mathrm{M}$ failure envelopes: $\mathrm{S}_{\mathrm{ubs}} / \mathrm{S}_{\mathrm{ut}}$ $=0.6 ; \mathrm{d} / \mathrm{t}_{\mathrm{c}}=0.5 ; \mathrm{t}_{\mathrm{c}} / \mathrm{B}=0.2$

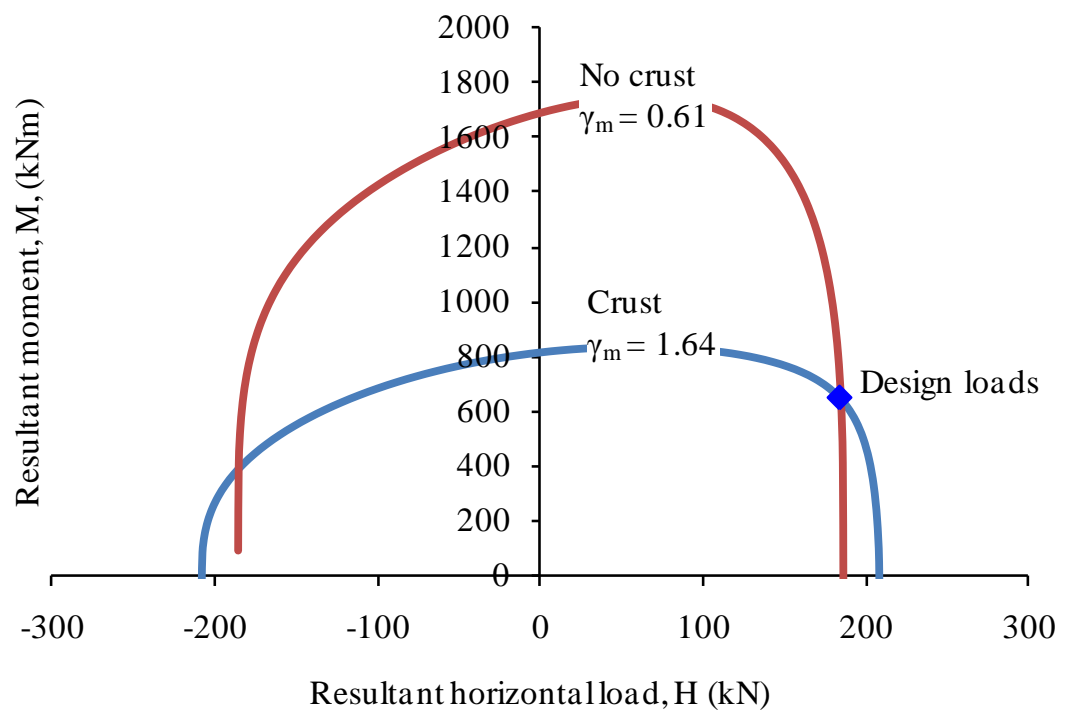

Figure 25 Loading conditions and failure envelopes for example application 1 